\title{
Mitochondria: a critical target in the toxicity of trichothecenes and potential treatment strategies
}

\author{
Deyu Huang1, Luqing Cui², Qinghua Wu ${ }^{3,4}$, Hafiz I. Hussain², Menghong Dai², \\ Zainab Fatima ${ }^{2}$, Xu Wang ${ }^{2}$ and Zonghui Yuan ${ }^{1,2}$ \\ ${ }^{1}$ Department of Animal Sciences \& Technology, Key Laboratory for the Detection of Veterinary Drug Residues, Huazhong \\ Agricultural University, Wuhan, China \\ ${ }^{2}$ Department of Animal Sciences \& Technology, Laboratory of Quality \& Safety Risk Assessment for Livestock and Poultry \\ Products, Huazhong Agricultural University, Wuhan, China \\ ${ }^{3}$ Department of Life Science, Institute of Biomedicine, Yangtze University, Jingzhou, China \\ ${ }^{4}$ Department of Chemistry, Faculty of Science, University of Hradec Kralove, Hradec Kralove, Czech Republic \\ Correspondence to: $X \cup$ Wang, email: Wangxu@mail.hzau.edu.cn \\ Zonghui Yuan, email: yuan5802@mail.hzau.edu.cn \\ Keywords: trichothecene; mitochondria; oxidative stress; microRNA; apoptosis \\ Received: November 13, $2017 \quad$ Accepted: January 02, $2018 \quad$ Published: January 09, 2018 \\ Copyright: Huang et al. This is an open-access article distributed under the terms of the Creative Commons Attribution License \\ 3.0 (CC BY 3.0), which permits unrestricted use, distribution, and reproduction in any medium, provided the original author and \\ source are credited.
}

\section{ABSTRACT}

Trichothecenes are secondary metabolites produced by fungi of genus Fusarium. It was known that trichothecenes can bind to the 605 subunit of the eukaryotic ribosomes, resulting in inhibition of protein synthesis. However, emerging evidences suggest that trichothecenes can target the mitochondria to induce mitochondrial dysfunction and mitochondria-dependent apoptosis. Numerous studies have investigated the mitochondria-associated toxicities induced by trichothecenes. Here, we mainly collected the data associated with mitochondria and its relationship with trichothecene-induced toxic effects. We showed that mitochondria are the main site of reactive oxygen species production and mediate the trichothecene-induced apoptosis in various cells. The mitochondrial membrane permeabilization plays critical roles in this apoptotic process. Trichothecenes can penetrate the mitochondrial membrane due to its amphiphilic property, and inhibit the activities of mitochondrial respiratory chain complexes and electron transfer in mitochondria. Besides, trichothecenes reduce the mitochondrial biogenesis and mitochondrial transcription and translation. Peroxisome proliferator-activated receptor- $\gamma$ co-activator $1 \alpha$ and mammalian target of rapamycin pathway are closely linked to this process. Trichothecenes can activate various microRNAs that may mediate the protein synthesis inhibition. These microRNAs may have a crosstalk with mitochondria to mediate the mitochondrial dysfunction and transcription repression in mitochondrial genome. Numerous natural compounds have been tested for their effective antioxidant and anti-inflammatorycapacities. Specially, mitochondria-targeted antioxidants and mitophagy exhibit outstanding cytoprotective abilitysince they can reduce the mitochondrial reactive oxygen species and maintain the mitochondrial quality. This review may shed some new light on the mitochondriaassociated mechanism underlying the toxicity of trichothecenes and new preventive ways to combat these mycotoxins. 


\section{INTRODUCTION}

Trichothecenes are a large family of secondary metabolites commonly found as contaminants in global cereals [1]. These mycotoxins were reported to be closely linked to alimentary toxic aleukia and Kashin-Beck disease in humans, and Fusarium head blight in cereal plants. Trichothecenes are divided into four types (AD) depending on their characteristic functional groups [2] (Figure 1), and type A and B are greater food safety concerns because of their high toxicity and frequent occurrence in cereals, feed and food for animals and humans $[2,3]$. The acute uptake of trichothecenes will cause a wide variety of toxic responses in humans and animals, including gastrointestinal irritation, emesis, diarrhea, hemorrhage, leukopenia, immunosuppression and mortality $[4,5]$.

Ribosomes are classic target for trichothecenes because these mycotoxins are able to bind to the $60 \mathrm{~S}$ subunit of the eukaryotic ribosomes [6, 7]. It was reported that type $\mathrm{A}, \mathrm{B}$ and $\mathrm{D}$ of trichothecenes, $\mathrm{T}-2$ toxin, deoxynivalenol (DON) and satratoxin $\mathrm{G}(\mathrm{SG})$ promoted intracellular $28 \mathrm{~S}$ ribosomal RNA cleavage in RAW 264.7 macrophages [8, 9]. SG was also found to specifically interact with $40 \mathrm{~S}$ and $60 \mathrm{~S}$ ribosomal subunit as early as 5 minutes and led to polysome disaggregation in RAW 264.7 cells [10]. It has been suggested that trichothecenes targeted the ribosomal protein L3 (Rpl3) at the peptidyltransferase centre of $60 \mathrm{~S}$ subunit, which led to protein synthesis inhibition [11, 12]. Heterogenous expression of $\mathrm{N}$-terminal fragment of yeast $\mathrm{Rpl3}$ in tobacco conferred resistance to DON [13]. Another report also showed that expression of modified tomato Rpl3 (double mutations in amino acid residues 258 and 259) in transgenic tobacco reduced the susceptibility to DON [14]. The binding of trichothecenes to the ribosomes could trigger a toxic response termed ribotoxic stress response (RSR), which was involved in rapid phosphorylation of mitogen-activated protein kinases (MAPKs, including ERK, JNK and p38) $[15,16]$.

Emerging evidences suggested that mitochondria were another important target for trichothecenes $[17,18]$. Earlier study have indicated that trichothecenes could be rapidly absorbed by the mitochondria from rat liver as early as 2 minutes at $37{ }^{\circ} \mathrm{C}$ in a dose-dependent manner [19]. T-2 toxin and DON were shown to change the normal ultrastructural morphology of mitochondria, including formation of megamitochondria, mitochondrial swelling and collapse in mitochondrial cristae in various mammal cells in vitro after exposure to these myctoxins [17, 2022]. In consideration of the fatal role of mitochondria in the oxidative phosphorylation (OXPHOS), $\mathrm{Ca}^{2+}$ and redox homeostasis and coordination of apoptotic signals, the serious damage to mitochondria is almost lethal to the cells. Furthermore, mitochondria are the major source of reactive oxygen species (ROS), except the NADPH oxidase. Aberrant ROS generation will initiate oxidative stress and is harmful to lipid, protein and DNA. ROS in turn will attack the mitochondria itself due to the close vicinity.

During the last decades, numerous investigations have examined the mitochondrial dysfunction and

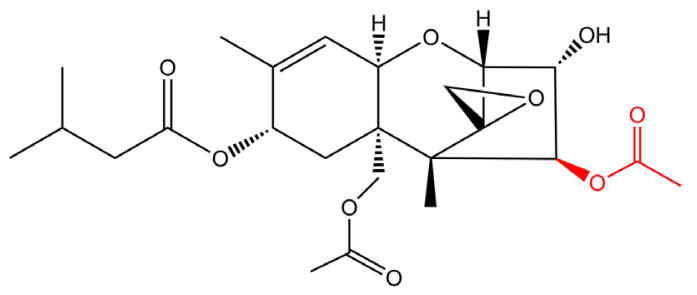

Type A: T-2 toxin

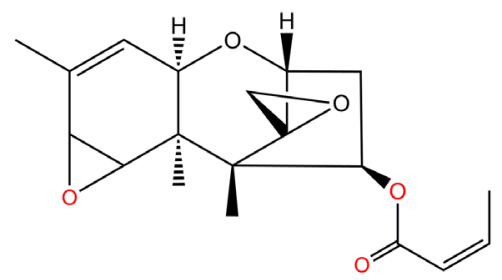

Type C: Crotocin

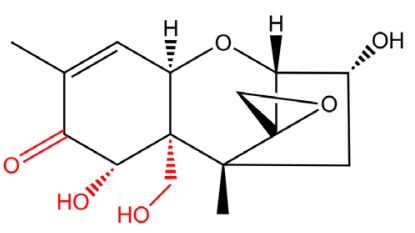

Type B: Deoxynivalenol

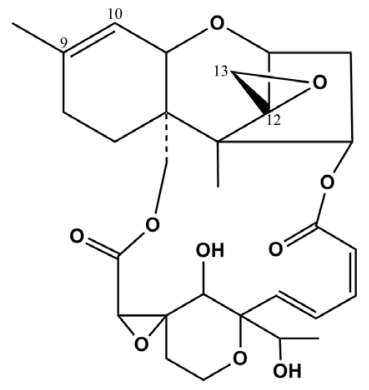

Type D: Satratoxin G

Figure 1: Chemical structures of type (A, B, C and D) trichothecenes [2]. The five positions (R1-R5) where the functional groups vary are shown in T-2 toxin. 
mitochondria-associated toxic effects like apoptosis caused by trichothecenes, but the data summarizing these information are limited. Thus, the aim of the present review is to summarize the existing data on the role of mitochondria in trichothecene-induced toxicity and the mitochondrial damage induced by trichothecenes.

\section{Mitochondria: the ROS source caused by trichothecenes}

Trichothecenes can contribute to ROS generation in vivo and in vitro, leading to oxidative stress [23, 24]. Although ROS generation and mitochondrial dysfunction caused by trichothecenes have been observed in common studies, few studies established direct link showing that mitochondria are the primary site of trichothecene-induced ROS generation. It was reported that in Saccharomyces cerevisiae, T-2 toxin strongly downregulated the genes associated with mitochondrial function and biogenesis, but upregulated the genes responsive to oxidative stress. T-2 toxin also significantly increased the ROS levels [25]. Exposure of rat granulosa cells and embryo fibroblast cells (DF-1) to T-2 toxin and/or DON revealed ROS accumulation and loss of $\Delta \psi \mathrm{m}[23,24]$. Direct evidence showed that trichothecenes could significantly increase ROS generation in the parental yeast strain BY4743, but not in the petite strain that has a defect in the respiratory chain [18]. Pretreatment of parental yeast strain BY4743 with mitochondrial membrane uncoupler, carbonyl cyanide 4-(trifluoromethoxy)phenylhydrazone that permeabilized the mitochondrial inner membrane, did not increase the ROS levels in trichothecene-treated cells [18], which suggested that mitochondria were undoubtedly the main site of ROS in trichothecene-treated cells. Moreover, this was validated by the observation that the elimination of damaged mitochondria caused by trichothecenes by mitophagy could reduce the ROS levels and confer resistance to these toxins [18].

\section{Trichothecenes induce mitochondria-dependent apoptosis}

Apoptosis is a tightly regulated process and plays an essential role in normal embryonic and postembryonic development as well as in pathological circumstances [26]. This process can be triggered by caspase-dependent mitochondrial pathway, caspase-independent apoptosisinducing factor (AIF) pathway and death receptor pathway. Mitochondria act as a central integrator and coordinator in this apoptotic process [27]. In this review, we will discuss the mitochondria-mediated apoptotic pathway and AIF apoptotic pathway.

Molecular mechanisms, including the disruption of mitochondrial electron transport and energy metabolism, release of mitochondrial proteins cytochrome c (cyt-c) and AIF, and alteration in mitochondrial redox homeostasis were proposed for mitochondria-controlled apoptosis [28]. Disruption of electron transport leading to ROS production has been considered an early feature in apoptosis [29]. Indeed, trichothecenes have been reported to disrupt the mitochondrial electron transport and led to ROS generation in cardiomyocytes of rats [30]. The released ROS in turn cause damage to DNA, lipid and protein, shifting the cells into a more oxidising environment [31]. Disruption of electron transport can gradually decrease the ATP levels, which lead the cells into the death process slowly. For example, in human chondrocytes, T-2 toxin (1, $10,20,100 \mathrm{ng} / \mathrm{ml})$ treatment for $1-5$ days decreased the viabilities in concentration- and time-dependent manners. $\mathrm{T}-2$ toxin $(10$ and $20 \mathrm{ng} / \mathrm{ml}$ ) also significantly reduced the $\Delta \Psi \mathrm{m}$ and decreased the cellular ATP levels by $20 \%$ and $27 \%$, respectively [32].

Increasing evidences indicated that trichothecenes induced apoptosis through caspase-dependent mitochondrial pathway in various cells in vitro $[33,34]$. Mitochondria-dependent apoptosis involves the opening of mitochondrial permeability transition pore (mPTP) formed in the inner membrane (IM), which causes $\Delta \Psi \mathrm{m}$ dissipation (or mitochondrial depolarization) and mitochondrial matrix swelling. This matrix volume expansion can eventually cause outer membrane (OM) rupture due to that the surface area of IM with its folded cristae is larger than OM. Downstream of this, pro-apoptotic protein like cyt-c located within the intermembrane space is released into the cytoplasm to activate caspases that execute apoptosis. For example, it has been reported that trichothecene-induced apoptosis was accompanied with the mPTP opening, loss of $\Delta \Psi \mathrm{m}$, cyt-c release, and caspase activation in HeLa cells [35], mice embryonic stem cells [23], rat ovarian granulosa cells [36], human colon carcinoma cells (HT-29 cells) [37], chicken splenic lymphocytes [38] and embryo fibroblast DF-1 cells [24]. Specially, the study of Bouaziz et al. [35] showed that T-2 toxin may directly act on mitochondria of mouse liver to induce mPTP opening because T-2 toxininduced mitochondrial depolarization and swelling was greatly inhibited by cyclosporin A (CsA), an inhibitor of mPTP. Furthermore, the mitochondrial membrane permeabilization (MMP) caused by this toxin was remarkably delayed by adenine nucleotide translocate (ANT, a critical mPTP member) inhibitor, suggesting that T-2 toxin may directly targeted ANT [35]. However, in the study of Bensassi et al., DON indeed induced loss of $\Delta \Psi \mathrm{m}$ and $\mathrm{mPTP}$ opening, but induced neither depolarization nor swelling of mitochondria in HT-29 cells. Contrarily, the positive control calcium induced both a dose dependent depolarization and swelling, which was greatly inhibited by CsA. This result indicated that DON did not directly target MPTP to induce MMP [37]. DON-induced MMP may be partially result from the interaction of proapoptotic protein Bax with the MPTP complex since Bax invalidation could partially protected cells against DON- 
induced loss of $\triangle \Psi \mathrm{m}$ and $\mathrm{mPTP}$ opening [37]. Previous study have also suggested that ROS could promote MMP by oxidizing the protein of MPTP complex [39]. This was confirmed by that antioxidant trolox significantly alleviated T-2 toxin-induced ROS generation and loss of $\Delta \Psi \mathrm{m}$ [36], suggesting that ROS should be another mechanism underlying T-2 toxin-induced MMP.

AIF is a mitochondrial flavoprotein with prolife and pro-death activities. It has significant roles in mitochondrial respiratory chain and caspase-independent apoptosis [40]. Normally, AIF resides in the mitochondrial OM, but moves to the cytosol when the mitochondria are damaged, and finally to the nucleus to cause DNA fragmentation and chromatin condensation [40]. In HeLa cells, T-2 toxin-induced apoptosis was accompanied with a progressive decrease of AIF protein level in mitochondrial fraction and a corresponding increase in cytosol fraction, suggesting that the AIF apoptotic pathway was activated. This was confirmed by the observation that broad spectrum caspase inhibitor z-VAD-FMK could not inhibit AIF mediated oligonucleosomal DNA fragmentation [41]. DON-induced apoptosis in DF-1 cells was partly due to the increase of the mitochondrial AIF-1 expression [24]. Similarly, SG induced apoptosis in PC-12 neuronal cells possibly through AIF apoptotic pathway [42].

\section{Trichothecenes inhibit mitochondrial function}

Mitochondria are described as the "powerhouse" of cells since the main mitochondrial function is to produce energy in the form of ATP by the mitochondrial respiratory chain, also known as the electron transport chain (ETC) [43]. ETC is composed of five multi-subunit enzyme complexes (I-V) embedded within the mitochondrial IM, three of which (I, III and IV) generate proton motive force, driving the $\mathrm{F}_{1} \mathrm{~F}_{0}$-ATPase $(\mathrm{V})$. A series of electron carriers accept and pass the electrons through the mitochondrial complexes, coenzyme Q and cyt-c and finally to the molecular oxygen to form water [43] (as show in Figure 3). Mitochondria also participate in lipid metabolism and $\mathrm{Ca}^{2+}$ uptake and release to shape cellular $\mathrm{Ca}^{2+}$ dynamics [44]. Besides, mitochondria generate a basal level of ROS, although as a by-product of ATP production. ROS can function as a second messager in cellular signaling transduction [45].

It was reported that $\mathrm{T}-2$ toxin in comparatively low doses of $10-50 \mu \mathrm{M}$ inhibited the activity of mitochondrial complex II (succinate dehydrogenase). Interestingly, T-2 toxin in higher doses of $100-200 \mu \mathrm{M}$ increased the activity of mitochondrial complex I (NADH dehydrogenase), but decreased the oxygen consumption of whole cells and purified mitochondria of yeast cells [46]. In human chondrocytes, T-2 toxin (42.87 nM) treatment for 5 days significantly decreased the activities of mitochondrial complex III (coenzyme Q-cytochrome c reductase), complex IV (cytochrome c oxidase) and complex V
(ATP synthase), and induced loss of $\Delta \Psi \mathrm{m}$, decrease of ATP levels, and ROS generation, which however, were reversed by selenium [32]. Similarly, T-2 toxin and DON significantly decreased the respiration rate of electron transport systems of rat liver cells. However, the treatment of cells with antioxidants, catalase and vitamin $C$ could reverse the decrease of respiration rate [30]. Recently, by using a yeast knock-out library, McLaughlin et al. [47] screened the genes whose deletion from the wild-type strain of yeast cells conferred resistance to trichothecin. The results revealed the largest group of resistant strains affecting mitochondrial function.

Peroxisome proliferator-activated receptor- $\gamma$ co-activator $1 \alpha(\mathrm{PGC}-1 \alpha)$ is a potent transcription coactivator involved in thermogenesis, mitochondrial biogenesis and respiration [48]. This co-activator binds nuclear respiratory factor (NRF-1 and NRF-2) and trans-activate the target genes of NRFs. NRFs in turn translocate to nucleus and bind the recognition sites within the promoters of mitochondrial transcription factors mTFA, TFB1M and TFB2M leading to increased mRNA expression [49]. mTFA, TFB1M and TFB2M are essential in maintaining mitochondrial DNA (mt-DNA) copy number and mt-DNA transcription and replication [50]. Previous study reported that DON upregulated the expression of My-binding protein $1 \alpha$ (Mybbp-1 $\alpha$ ), which is a known repressor of PGC-1 $\alpha$ [51]. Another study showed that $\mathrm{T}-2$ toxin decreased the mitochondrial number and the protein expression of PGC- $1 \alpha$, NRF-1, mTFA and COX IV in a time-dependent manner in murine embryonic stem cells [52]. These studies indicated that trichothecenes may inhibit the mitochondrial function and mitochondrial transcription by decreasing the expression of PGC- $1 \alpha$, NRFs, mTFA, TFB1M and TFB2M.

The toxicity of trichothecenes is closely related to the mammalian target of rapamycin (mTOR) signaling pathway. It was reported that DON inhibited the mTOR pathway by reducing phosphorylation levels of phosphoinositide 3-kinase (PI3K)/protein kinase B (Akt) pathway [53]. Deletion mutation of some mTOR pathway genes in Saccharomyces cerevisiae was shown to alter the susceptibility of cells to T-2 toxin [25]. The inhibition of mTOR pathway could decrease the phosphorylation levels of eukaryotic initiation factor 4E-binding protein 1 (4EBP1) and inhibit ribosomal S6 kinase (S6K), which resulted in reduced cytoplasmic and mitochondrial protein translation. The inhibition of mTOR could decrease the expression of PGC-1 $\alpha$, leading to decreased mitochondrial gene expression and oxygen consumption [54].

\section{Trichothecenes inhibit mitochondrial translation}

Trichothecenes target the mitochondrial translation process to inhibit mitochondrial protein synthesis. It has been reported that T-2 toxin decreased the total amount of leucine incorporated into mitochondrial proteins 
by $50 \%$ in amino acid incorporation assay [19]. New evidences suggested that type A and B trichothecenes had direct inhibitory effects on mitochondrial translation in yeast cells, which was independent of their effects on cytoplasmic translation and disruption of mitochondrial membranes [55]. Transcriptomic analysis revealed that $\mathrm{T}-2$ toxin (10.72 $\mu \mathrm{M}$ for $2 \mathrm{~h}$ ) strongly repressed the genes involved in mitochondrial translation, including mitochondrial translation initiation factor IF-2 and elongation factor $\mathrm{G}$, mitochondrial $37 \mathrm{~S}$ ribosomal protein MRP13, mitochondrial 37S ribosomal protein S19, mitochondrial ribosomal modulation factor 2, mitochondrial ribosomal protein L13, mitochondrial isoleucine-tRNA ligase and mitochondrial valine-tRNA ligase in yeast cells [25]. Similarly, DON, nivalenol (NIV, a type B trichothecene) and their derivatives 3-acetyldeoxynivalenol (3-AcDON), 15-AcDON, and 4-acetylnivalenol (4-AcNIV) in highly toxic conditions ( $25 \mathrm{ppm}$ for 2 days) exerted significant repression effect on genes encoding mitochondrial ribosomal proteins in yeast [56]. However, another study showed that DON upregulated those genes associated with mitochondrial structure, function, metabolism and mitochondrial ribosomal proteins in human T lymphocyte cells Jurkat (0.25 and $0.5 \mu \mathrm{M}$ DON for 3, 6 and $24 \mathrm{~h}$ ) and human peripheral blood mononuclear cells ( 2 and $4 \mu \mathrm{M}$ DON for 6 and $24 \mathrm{~h}$ ) [57]. The doses of these mycotoxins and exposure time were critical in determining the toxic responses. The exact mechanism by which trichothecenes inhibit the mitochondrial protein synthesis has not been elucidated fully. Since mitochondria have their own DNA, RNA and ribosomes (mitoribosome), and both mitochondrial and cytoplasmic ribosomes have a peptidyl transferase catalytic centre on their large subunit [58]. Trichothecenes may directly target the mitochondrial translation machinery to inhibit mitochondrial protein synthesis, as they do to cytoplasmic ribosomes. But the exact site in mitochondria remains to be determined.

Trichothecenes also changed the expression of mitochondrial ETC subunits. The proteomic analysis showed that T-2 toxin increased the expression of all of the mitochondrial proteins identified in chicken primary hepatocytes, including two subunits of complex I, NADH dehydrogenase iron-sulfur protein 8 and NADH dehydrogenase 1 beta subcomplex subunit 10 . T-2 toxin also significantly increased the ROS levels [59]. Similarly, T-2 toxin increased the protein expression of mitochondrial subunits NADH dehydrogenase iron-sulfur protein 1, NADH dehydrogenase 1 alpha subcomplex subunit 9 and cytochrome b-c1 complex subunit 1 and the proteins responsive to oxidative stress in porcine primary hepatocytes [60]. The protein expression of NADH dehydrogenase iron-sulfur protein 3 and cytochrome c oxidase subunit $6 \mathrm{C}$ in $\mathrm{GH} 3$ were decreased by $\mathrm{T}-2$ toxin, accompanying with ROS generation [61]. T-2 toxin strongly decreased mitochondrial NADH dehydrogenase subunit 1 and cytochrome c oxidase subunit 1, 2 and 3, while strongly increased heat shock protein 70 , heme oxygenase-1 and $\mathrm{Cu}$, $\mathrm{Zn}$-superoxide dismutase in the foetal brain of pregnant rats [62]. The changes in expression of mitochondrial ETC subunits, particularly the iron-sulfur protein-containing subunits, can decrease the coupling efficiency of mitochondrial OXPHOS, resulting in decreased ATP levels and increased ROS [63]. The trichothecene-induced alterations in the expression of mitochondrial ETC subunits may be related to the mitochondrial dysfunction and ROS generation.

\section{Crosstalk between mitochondria and microRNAs and its significance in trichothecene toxicity}

MicroRNAs (miRNAs) are small noncoding RNAs that function in post-transcriptional regulation of gene expression by either mRNA degradation or translational repression [64, 65]. The actions of miRNAs require the cytoplasmic processing by Dicer, interaction with Argonaute (AGO, miRNA processing proteins) and assembly into RNA induced silencing complexes (RISC) [66]. miRNAs have been implicated in the etiology, progression and prognosis of cancer and other diseases including cardiovascular diseases and neurodegeneration $[66,67]$.

There has been a crosstalk between mitochondria and miRNAs expression. The AGO has been identified in purified mitochondria from various cells and tissues [68, 69]. A study from Wang et al. further demonstrated that AGO was enriched in the mitochondrial OM and matrix purified from rat brain [68]. The nuclear encoded miRNAs have been found to be associated with mitochondrial OM, and can to be imported into mitochondria matrix [65]. This indicated that mitochondrial genome (matrix) as well as cytoplasmic gene expression (OM) may be potential sites for miRNA mediated post-transcriptional regulation. The mitochondrial OM may serve as a platform for the assembly of signaling complexes to mediated downstream transcriptional repression.

The evidences have demonstrated the presence of miRNAs in mitochondria. These miRNAs could fully or partially align to mitochondrial genome [65] (Table 1). For example, in the study of Bandiera et al. [69], the authors identified 57 miRNAs differentially expressed in mitochondria relative to cytosol, of which 13 miRNAs were enriched in mitochondria in HeLa cells. Computational targeting analysis showed that these mitochondrial miRNAs could align the target sites along the mt-DNA sequence (mostly align the sites located at ND1, ND4, ND5, ND6, COX1 and COX2) [69]. The study of Wang et al. demonstrated that 11 miRNAs were found to be at least 1.5 fold higher in mitochondria relative to cytosol in normal rat hippocampus, of which 4 miRNAs (miR142-3p, miR142-5p and miR-146a) were 
Table 1: List of miRNAs associated with mitochondria

\begin{tabular}{|c|c|c|c|c|}
\hline Species/cells/organ & $\begin{array}{c}\text { Mitochondria-associated } \\
\text { miRNAs }\end{array}$ & miRNAs functions & Conditions & Reference \\
\hline HeLa cells & $\begin{array}{l}\text { MiR-1973, miR-1275, } \\
\text { miR-494, miR-513a-5p, } \\
\text { miR-1246, miR-328, } \\
\text { miR-1908, miR-1972, } \\
\text { miR-1974, miR-1977, } \\
\text { miR-638, miR-1978 and } \\
\text { miR-1201 }\end{array}$ & $\begin{array}{l}{ }^{*} \text { Mitochondrial homeostasis, } \\
\text { ATP synthesis, electron } \\
\text { transport, mitochondrial } \\
\text { translation, cell cycle, mt-DNA } \\
\text { expression. }\end{array}$ & No treatment & [69] \\
\hline HeLa cells & MiR-346 & $\begin{array}{l}\text { Induce mitophagy to reduce } \\
\text { ROS, cyt-c release and } \\
\text { promote apoptosis. }\end{array}$ & $\begin{array}{l}\text { Under endoplasmic } \\
\text { reticulum stress }\end{array}$ & {$[83]$} \\
\hline $\begin{array}{l}\text { Cultured human } \\
\text { adult cardiac } \\
\text { myocytes }\end{array}$ & MiR-410 & $\begin{array}{l}\text { Inhibit ATP production, } \Delta \Psi \mathrm{m} \\
\text { and mitophagy level, and } \\
\text { increased caspase- } 3 \text { activity, } \\
\text { Bax expression and cyt-c } \\
\text { release. }\end{array}$ & $\begin{array}{l}\text { Cardiac ischemia } \\
\text { reperfusion injury }\end{array}$ & [84] \\
\hline Rat cardiomyocytes & MiR-22 & $\begin{array}{l}\text { Promote mitochondrial } \\
\text { superoxide production, } \Delta \Psi \mathrm{m} \\
\text { and ATP loss, reduce PGC-1 } \alpha \text {, } \\
\text { Sirt-1 expression. }\end{array}$ & $\begin{array}{l}\text { Cardiac ischemia } \\
\text { reperfusion injury }\end{array}$ & {$[85]$} \\
\hline Rat hippocampus & $\begin{array}{l}\text { MiR-142-3p, miR-142- } \\
\text { 5p, miR-146a, miR-150, } \\
\text { miR-741, miR-302a, } \\
\text { miR-339-3p, miR-10a, } \\
\text { miR-202-3p, miR-339-5p, } \\
\text { miR-344-5p }\end{array}$ & $\begin{array}{l}\text { *Inflammation, cell } \\
\text { proliferation and survival, } \\
\text { mitochondrial biogenesis, } \\
\text { energy metabolism, } \\
\text { synthesis of ETC subunits, } \\
\text { mitochondrial fatty acid } \\
\text { oxidation. }\end{array}$ & No treatment & {$[68]$} \\
\hline $\begin{array}{l}\text { Human skeletal } \\
\text { muscle of subject } \\
\text { groups }\end{array}$ & $\begin{array}{l}\text { MiR-320a, miR-150, } \\
\text { miR-196b, and miR-34c }\end{array}$ & $\begin{array}{l}{ }^{*} \text { ATP production, } \\
\text { mitochondrial fatty acid } \\
\text { oxidation, oxidative } \\
\text { phosphorylation, redox } \\
\text { potential, } \Delta \Psi \mathrm{m}, \text { mitochondrial } \\
\text { protein synthesis. }\end{array}$ & $\begin{array}{c}\text { Subjects displaying large } \\
\text { variation in mitochondrial } \\
\text { capacity. }\end{array}$ & [86] \\
\hline Mouse liver tissues & $\begin{array}{l}\text { MiR-134, miR-760, miR- } \\
\text { 155, miR-696, miR-361- } \\
\text { 5p, miR-181d, miR-680, } \\
\text { miR-296-3p, miR-689, } \\
\text { miR-744, miR-721, } \\
\text { miR-188-5p, miR-146a, } \\
\text { miR-202-5p }\end{array}$ & $\begin{array}{l}\text { "Aminoacylation of tRNA, } \\
\text { expression of mTFA, mt- } \\
\text { DNA transcription, oxidative } \\
\text { phosphorylation, ATP } \\
\text { synthesis. }\end{array}$ & No treatment & {$[70]$} \\
\hline Mouse heart tissues & $\begin{array}{l}\text { MiR-6538, miR-299a-5p, } \\
\text { 199a-5p, miR-5126, miR- } \\
\text { 532-5p, miR-148a-3p, } \\
\text { miR-208a-3p, miR-7225- } \\
\text { 5p, miR-133b-3p, miR- } \\
\text { 28a-3p, miR-146a-5p, } \\
\text { miR-709, }\end{array}$ & $\begin{array}{l}\text { *Fatty acid biosynthesis, } \\
\text { metabolism, and degradation; } \\
\text { thyroid hormone signaling, } \\
\text { Hippo, and FOXO pathways, } \\
\text { citrate cycle regulatory } \\
\text { pathway, energy metabolism. }\end{array}$ & $\begin{array}{l}\text { Induce heart failure for } 8 \\
\text { weeks }\end{array}$ & [87] \\
\hline
\end{tabular}




\begin{tabular}{|c|c|c|c|c|}
\hline Species/cells/organ & $\begin{array}{l}\text { Mitochondria-associated } \\
\text { miRNAs }\end{array}$ & miRNAs functions & Conditions & Reference \\
\hline Rat liver tissues & $\begin{array}{l}\text { MiR-130a, miR-130b, } \\
\text { miR-140, miR-290, miR- } \\
\text { 320, miR-494, miR-671, } \\
\text { miR-202, miR-705, } \\
\text { miR-709, miR-721, miR- } \\
\text { 761, miR-763, miR-198, } \\
\text { miR-765. }\end{array}$ & $\begin{array}{l}\text { *Apoptosis, cell proliferation, } \\
\text { and differentiation. }\end{array}$ & No treatment & {$[88]$} \\
\hline $\begin{array}{l}\text { Human skeletal } \\
\text { muscular cells }\end{array}$ & $\begin{array}{l}\text { MiR-720, miR-133b, } \\
\text { miR-1974, miR-24, miR- } \\
\text { 133a, miR-125a-5p, miR- } \\
\text { 1979, miR-103, miR- } \\
\text { 125b, miR-103, miR-221, } \\
\text { miR-23a, let-7b, miR- } \\
\text { 423-3p, miR-106a, miR- } \\
\text { 23b, miR-92a, miR-193b, } \\
\text { miR-365, miR-93, } \\
\text { miR-532-3p, miR-20a, } \\
\text { miR-149, miR-181a, miR- } \\
\text { 503, miR-210, miR-107, } \\
\text { miR-574-3p, miR-34a, } \\
\text { let-7g, miRPlus-D1033, } \\
\text { miR-19b, miR-197, miR- } \\
\text { 324-3p, miR-127-3p, } \\
\text { miR-324-5p, miR-484, } \\
\text { miR-151-5p, miR-486-5p, } \\
\text { miR-542-5p, miR-199a- } \\
\text { 5p, miR-501-3p, miR- } \\
\text { 675, miR-134, miR-490- } \\
\text { 3p, miR-598 }\end{array}$ & $\begin{array}{l}\text { *Mitochondrial energy } \\
\text { metabolism, post- } \\
\text { transcription regulation in } \\
\text { mt-DNA, electron transport, } \\
\text { mitochondrial translation, } \\
\text { cell proliferation, apoptosis, } \\
\text { mitochondrial fission, PGC- } \\
1 \text { expression, mitochondrial } \\
\text { oxidative phosphorylation, } \\
\text { ATP production. }\end{array}$ & No treatment & [89] \\
\hline HEK293 cells & $\begin{array}{l}\text { Let- } 7 b \text {, let7g, miR-107, } \\
\text { miR-181a, miR-221, miR- } \\
\text { 320a }\end{array}$ & $\begin{array}{l}\text { Regulation of transcription, } \\
\text { cell cycle and division, } \\
\text { chromatin modification, } \\
\text { ubiquitin mediated proteolysis } \\
\text { pathway, glucocorticoid } \\
\text { receptor signaling pathway. }\end{array}$ & No treatment & {$[90]$} \\
\hline $\begin{array}{l}\text { Human skeletal } \\
\text { muscular cells }\end{array}$ & $\begin{array}{l}\text { Let-7a, let-7b, let-7i, } \\
\text { let-7f, let-7g, miR-93, } \\
\text { miR-20a, miR-331-5b }\end{array}$ & $\begin{array}{l}{ }^{*} \text { Post-transcription regulation } \\
\text { in mt-DNA, regulation of } \\
\text { myogenesis, fibrosis and } \\
\text { oncogenic activities. }\end{array}$ & No treatment & [91] \\
\hline $\begin{array}{l}\text { Human keloid } \\
\text { fibroblasts }\end{array}$ & MiR-21 & $\begin{array}{l}\text { Inhibit mitochondrial fission } \\
\text { and induce MMP, inhibits } \\
\text { apoptosis. }\end{array}$ & No treatment & {$[71]$} \\
\hline Transgenic mice & MiR-484 & $\begin{array}{l}\text { Suppress translation of } \\
\text { mitochondrial fission } \\
\text { protein Fis } 1 \text { and resultant } \\
\text { mitochondrial fission and } \\
\text { apoptosis. }\end{array}$ & No treatment & {$[73]$} \\
\hline
\end{tabular}

Note: ${ }^{*}$ indicate that these miRNAs are found to be enriched in mitochondria. The miRNAs functions come from the Gene Ontology analysis and KEGG analysis. 
significantly enriched in mitochondria [68]. Similarly, in mouse liver, a subset of miRNAs (20 miRNAs) selectively enriched in mitochondria were identified [70]. Apart from the regulation of mitochondrial genome, other studies have also provided evidences that miRNAs were involved in regulating many events related to mitochondrial function like mitochondria-mediated apoptosis [71], OXPHOS and antioxidant enzymes [65], ROS activity and ATP generation [64], mitophagy [72], mitochondrial fission [73], energy metabolism [74], and fatty acid metabolism [64]. A schematic miRNAs biogenesis and translocation into the mitochondria to regulate mt-DNA expression is presented in Figure 2.

However, a hypothesis arise that mitochondria may function as a regulator of miRNA activity or expression in response to intracellular and extracellular signals, given that mitochondria serve as critical energy provider, stress responder and coordinator of lethal signals $[17$, $64,65]$. This need to be validated. However, in support of this, a study have demonstrated that compromised mitochondria could lead to delocalization of AGO from processing bodies (P-bodies, responsible for mRNA decay, mRNA storage and RNA interference (RNAi)), which led to a strong decrease of miRNA-mediated RNAi efficiency [75]. The mitochondrial ROS may also activate pathological miRNAs to mediate the development of heart diseases. It has been shown that ROS could bidirectionally alter the expression of miRNA-1 to contribute to the hypertrophy or apoptosis in the culture of rat ventricular cardiomyocytes [76].

Earlier study reported that DON could increase the expression of a large number of miRNAs in RAW 264.7 macrophages, and many of these miRNAs have sequences that complement ribosomal protein mRNAs [77]. This may explain the reason of translational inhibition caused by this mycotoxin. Another more recent study showed that DON $(12 \mu \mathrm{g} / \mathrm{kg} / \mathrm{d})$ administration in immature gilts (about 20 kilogram) significantly increased miR-21 expression (up to 50-folds) in the ascending colon after 7 days of treatment, while significantly decreased the miR-15a expression in the liver after 21 days of treatment [78]. MiR-21 is a key oncogenic miRNA that is significantly upregulated in the majority of cancers and functionally linked to cellular proliferation, survival and migration [79]. It was also found to be implicated in mitochondrial fission [71] and upregulation in mitochondrial translation [80]. MiR-15a is a direct transcriptional target of E2F1, which is a critical downstream target of tumor suppressor retinoblastoma [81]. MiR-15a overexpression could suppress oncogene BMI1 expression, resulting in mitochondrial dependent apoptosis in breast cancer cells [82]. In the study of [78], the upregulation of miR-21 in ascending colon may be involved in the promotion of cell proliferation and survival after a short exposure of gilts to DON. While downregulation of miR-15a may indicate that long exposure to DON have a pro-apoptotic effect on the liver cells of gilts.

\section{The trichothecenes, oncogenes and mitochondria}

Oncogenes are genes that has the potential to cause cancers due to their high mutation frequency and/ or high expression levels. Oncogenes is mainly involved in promotion of cell growth, inhibition of apoptosis and transducing signal for proliferation and differentiation [82].

It has been suggested that trichothecenes upregulated the expression of oncogene Ras and Raf in various cells and in mouse skin in vivo $[92,93]$. The Ras protein provided an essential role in transducing the signals to the downstream PI3K/Akt, ERK, JNK and p38 MAPK signaling pathway in human neuroblastoma cells [93] and in mouse skin [92] and also established a crosstalk between JNK1 and signal transducer and activator of transcription 3 (STAT3) to maintain the normal function of the mitochondria in RAW264.7 cells [94]. Trichothecenes has also been shown to increase the expression of oncogenes c-fos, c-JUN, Src, and c-Myc in rat keratinocyte primary cultures [95], human primary macrophages [96], and human neuroblastoma cells [93] in vitro and in liver, placenta and fetal liver of pregnant rats [97], dorsal skin of hypotrichotic WBN/ILA-ht rats [98] in vivo. The upregulation of these oncogenes are closely related to the mitochondrial dysfunction and apoptosis in trichothecene-treated cells [99].

\section{A brief summary of the knowledge described above}

Collectively, the findings above suggest that trichothecenes can not only bind to ribosomes, but also target mitochondria to cause ROS generation and oxidative stress. Via RSR, trichothecenes activate MAPKs signaling pathway that mediate the activation of other signaling pathways such as JAK/STAT and NF- $\mathrm{kB}$ and downstream transcription factors $[16,94]$. Trichothecenes can induce apoptosis through caspase-dependent mitochondrial pathway, AIF pathway and death receptor pathway, the first two of which are closely related to mitochondrial permeabilization in IM and OM. Trichothecenes can inhibit the mitochondrial function by changing the activities of respiratory chain complexes and by inhibiting the mitochondrial biogenesis and mitochondrial translation. Besides, trichothecenes can increase the expression of various miRNAs. These miRNAs could be involved in trichothecene-induced inhibition of protein synthesis and may translocate to mitochondria matrix to regulate mt-DNA transcription and other mitochondriaassociated events. Trichothecenes can also activate oncogene expression like Ras, Raf, c-fos, c-JUN, Src and c-Myc, which are mainly responsible for the signal 


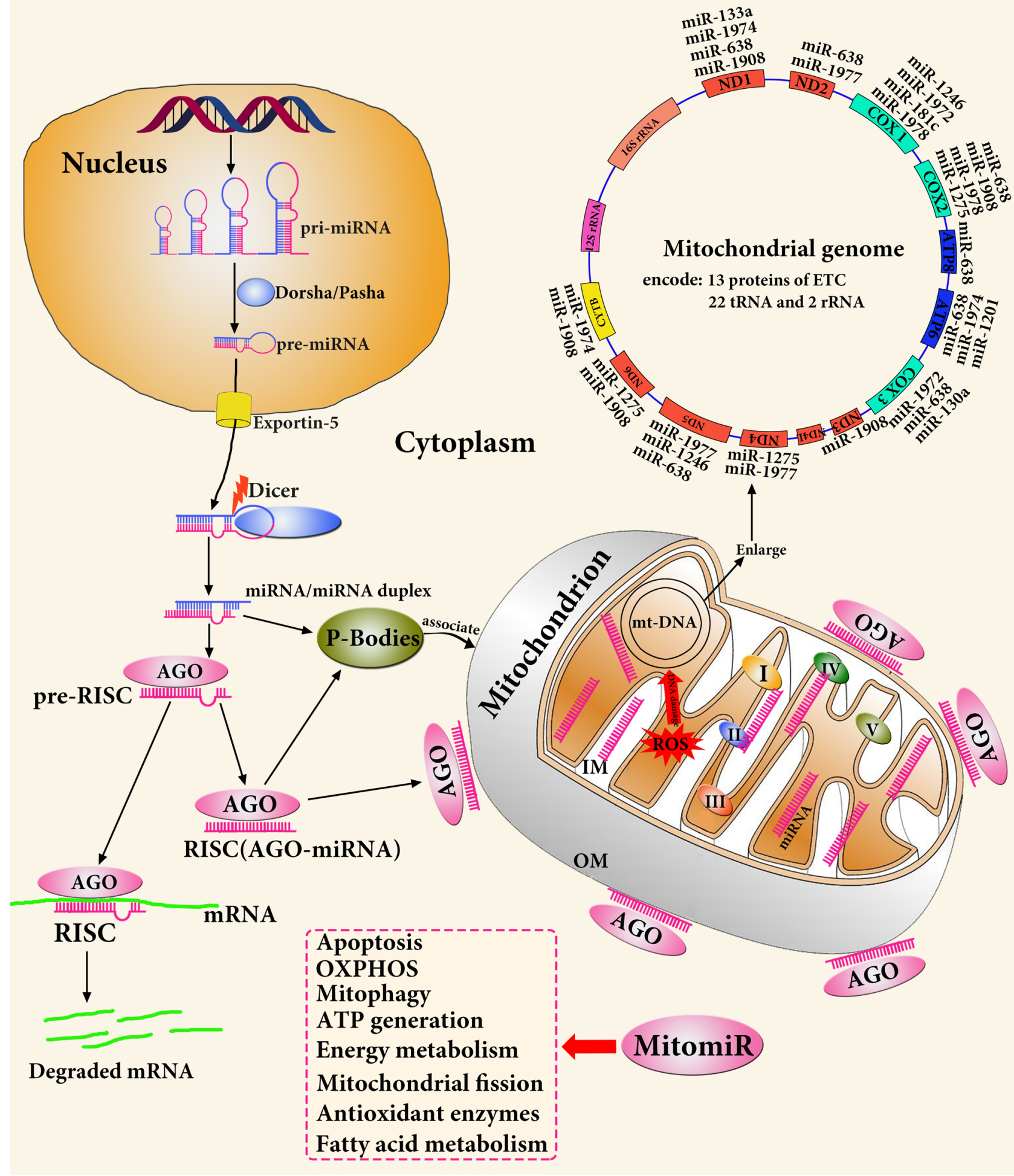

Figure 2: The pri-miRNA is transcribed from nuclear genome by RNA polymerase II, followed by process to form pre-miRNA by RNase III enzyme Dorsha and its partner Pasha. The pre-miRNA is translocated to the cytosol by Exportin- 5 and is cleaved by Dicer to produce mature miRNA that then becomes a component of RISC assembly. RISC can degrade the targeted mRNA. Mature miRNA are translocated to various subcellular compartments including P-bodies and mitochondria. P-bodies and miRNA-AGO assembly can associate with mitochondrial OM. miRNA may be translocated to the mitochondrial matrix to align with mt-DNA target sites [65]. Mitochondrial miRNA (MitomiR) are also involved in many other mitochondria-associated events as shown in the figure. 
transduction and mitochondria-dependent apoptosis. The schematic mechanism of trichothecene-induced toxicities related to mitochondria is presented in Figure 3.

\section{Prevention of trichothecene-mediated oxidative stress}

Dietary use of free radical scavenger is a classic and useful approach to combat trichothecene-induced oxidative stress. For example, quercetin, an active flavonoid with anti-inflammatory and antioxidant properties, exerted its beneficial effects by maintaining the total antioxidant status and activities of superoxide dismutase (SOD) and glutathione peroxidase (GSH-Px) in porcine granulosa cells exposed to T-2 toxin [100]. Lutein is a non-vitamin A carotenoid commonly found in high quantities in green leafy vegetables such as spinach, kale and yellow carrots [20]. Lutein was shown to protect the HT-29 cells against DON-induced inflammation and apoptosis. The mechanisms included that this compound could combat DON-induced oxidative stress, downregulate expression of inflammatory genes, NF- $\kappa \mathrm{B}$ and cyclooxygenase-2 (COX2 ) and prevent $\mathrm{DON}$-induced ultrastructural changes in mitochondria [20]. The cytoprotective effect of green tea polyphenol epigallocatechin 3-gallate (EGCG) on DONinduced toxicity through decreasing the ROS levels and downregulation of NF- $\kappa \mathrm{B}, \mathrm{COX}-2$ and caspase- 3 activated apoptosis in HT-29 cells was reported [101]. Spirulina, a blue-green algae, possess numerous health benefits, including antioxidant, anti-inflammatory, anti-cancer, antiviral, and anti-bacterial activities. Supplementation with Spirulina has been shown to reduce lipid peroxidation and DNA damage, increase GSH content, and upregulate expression of the antioxidant enzyme GSH-Px [102].

During in vivo studies, it was reported that dietary nucleotide had a potency to reduce the extent of DNA damage in spleen leukocytes of male broiler chickens exposed to T-2 toxin (10 mg/kg b.w.) [103]. The prevention

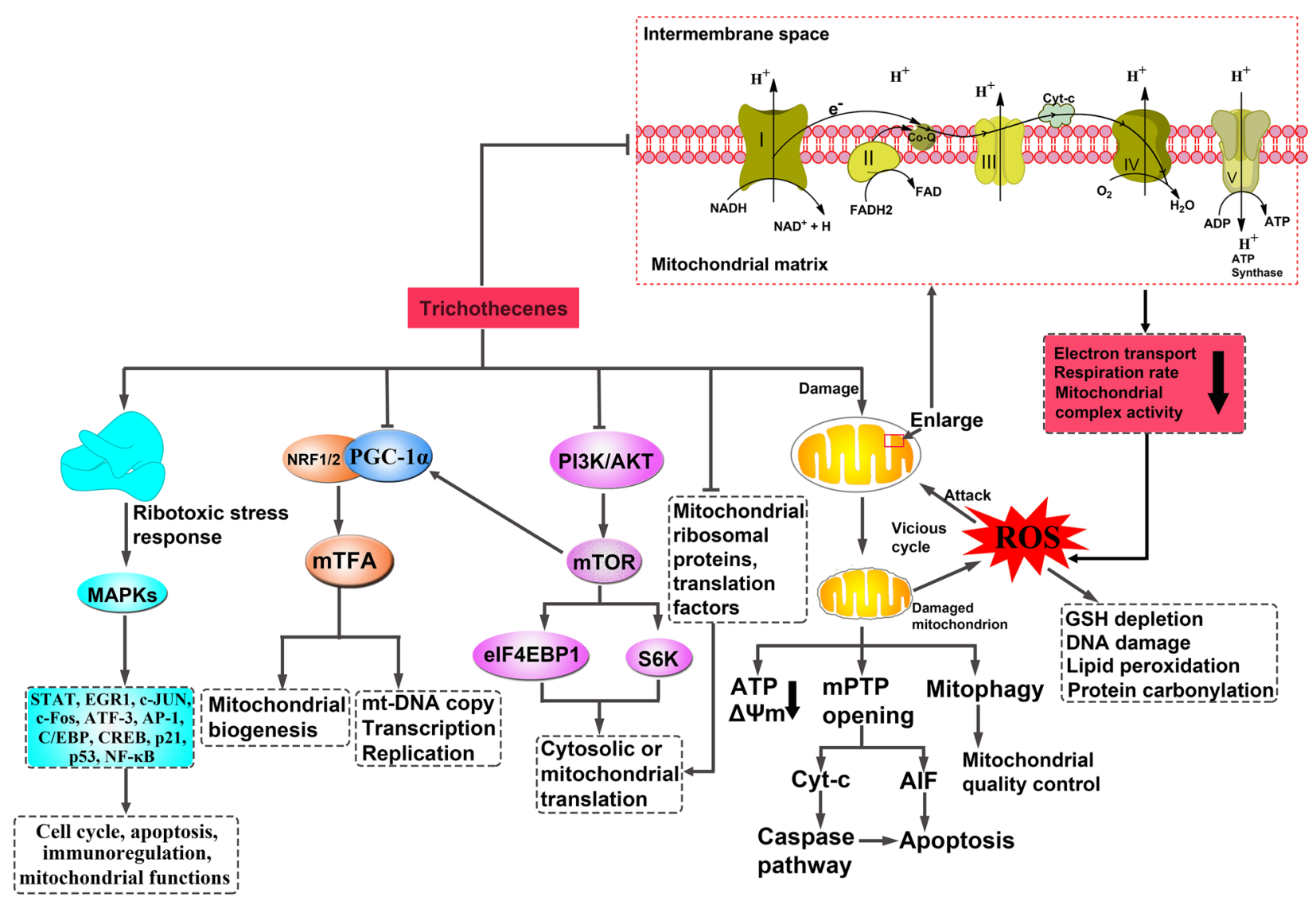

Figure 3: A schematic mechanism of trichothecene-induced toxicities related to mitochondria. Trichothecenes activate the RSR to mediate activation of MAPKs and downstream transcription factors. Trichothecenes inhibit PGC-1 $\alpha / \mathrm{NRF} / \mathrm{mTFA}$ and PI3K/ AKT/mTOR-S6K/4EBP1 pathways and mitochondrial ribosomal proteins and translation factors to reduce mitochondrial biogenesis and mitochondrial translation. Trichothecenes open the mPTP to induce cyt-c and AIF release, both of which activate caspase-dependent and -independent apoptosis. The damaged mitochondria are the major site of ROS trichothecene-treated cells. ROS damage the DNA, protein and lipid, and attack the healthy mitochondria. When mitochondria are seriously damaged, mitophagy is activated to selectively remove them and reduce the ROS. Trichothecenes inhibit the activity of mitochondrial electron transport systems, resulting in decreased mitochondrial respiratory and complex enzyme activities. 
of pig lymphocyte DNA damage caused by T-2 toxin or DON by vitamin E was also documented [104]. A combination of glucomannans with organic selenium was shown to provide protective effects against $\mathrm{T}-2$ toxininduced antioxidant depletion and lipid peroxidation in the chicken liver [105]. Addition of vitamin C, E and selenium to feed of rats administered orally a single dose of DON $(28 \mathrm{mg} / \mathrm{kg}$ b.w.) or T-2 toxin $(3.6 \mathrm{mg} / \mathrm{kg} \mathrm{b.w.})$ provided protective effects against trichothecene-induced lipid peroxidation, glutathione (GSH) depletion and decrease in the activities of SOD, catalase (CAT) and glutathione S-transferases (GST) [106]. Selenium could alleviate DONinduced oxidative damage in piglet splenic lymphocytes possibly by reversing the inactivation of antioxidant enzymes GSH-Px, SOD, CAT and GSH depletion and by decreasing the malondialdehyde (MDA) and $\mathrm{H}_{2} \mathrm{O}_{2}$ levels [107]. Similarly, glutamic acid remarkably reduced DON-induced (4 mg/kg b.w.) increase in $\mathrm{H}_{2} \mathrm{O}_{2}$, nitric oxide (NO), MDA levels and decrease in CAT activity and total antioxidant capacity (TAC) in blood and liver, kidney and intestinal tissues of piglets challenged with DON for 37 days. Glutamic acid remarkably alleviated the increase in intestinal permeability [53]. Besides, glutamic acid reversed the inhibition of Akt $/ \mathrm{mTOR} / 4 \mathrm{EBP} 1$ signal pathway induced by DON [53], suggesting that glutamic acid may have a promise in combating the inhibition of protein synthesis caused by trichothecenes.

In the case that mitochondria is critical in trichothecene-induced apoptosis and ROS generation, mitochondria-targeted antioxidants that can improve mitochondrial function may have great promise in the prevention of trichothecene-induced oxidative stress [108]. L-carnitine has anti-apoptotic and anti-oxidative effects, and can facilitate the transportation of long-chain fatty acids into mitochondrial matrix. It was reported that 1-carnitine can protected hepatocytes isolated from rat against T-2 toxin-induced GSH depletion, ROS overproduction and $\Delta \Psi \mathrm{m}$ collapse. L-carnitine at a dose of $500 \mathrm{mg} / \mathrm{kg}$ also significantly reduced the toxicity in rat and prevented the hepatocytes from abnormal caspase-3 activity and apoptosis [109]. Co-enzyme Q10 (Co-Q10) is an endogenous compound found in the mitochondrial IM and is also an essential component in mitochondrial ETC. Co-Q10 deficiency can result in reduced activity of Co-Q10-dependent mitochondrial complexes and increased ROS production [110]. It was reported that Co-Q10 combined with vitamin $\mathrm{E}$ was beneficial in relieving the oxidative damage caused by T-2 toxin [111]. A combination of 1-carnitine and Co-Q10 also provided protection for bacterial growth in the presence of $\mathrm{T}-2$ toxin and DON [112]. Another important mitochondria-targeted antioxidant is the mitochondrial GSH. GSH is synthesised exclusively in the cytoplasm and then transported into the mitochondrial matrix [113]. Two inner membrane organic anion carriers, dicarboxylate and 2-oxoglutarate, are responsible for this transport. Overexpression of these two carriers can protect cells against oxidants- induced mitochondrial function alterations and reduce the susceptibility of cells to toxic compounds [114], suggesting that mitochondrial GSH carriers may be potential therapeutic targets in trichothecene-caused diseases. Other well-studied mitochondria-targeted antioxidants include MitoQ, MitoVitE, MitoTEMPOL and tiron. MitoQ, MitoVitE, MitoTEMPOL are consist of triphenylphosphonium (TPP) covalently conjugated to the ubiquinone moiety of Co-Q10, $\alpha$-tocopherol moiety of vitamin $\mathrm{E}$ and the stable piperidine nitroxide radical TEMPOL (4-hydroxy-2,2,6,6,-tetramethyl-piperidine-1oxyl), repectively [115]. The TPP is a lipophilic cation that help these compounds pass through biological membranes and accumulate within mitochondria to exert their protective effects against mitochondrial oxidative damage [115]. Tiron is a non-toxic iron chelator known to possess anti-oxidative properties. Some studies have shown that tiron have great potential in reducing ROS and mitochondrial and nuclear DNA damage in human skin cells and human lung cancer Calu-6 cells [116, 117].

Elimination of damaged mitochondria to reduce ROS level is another novel strategy. Autophagic delivery to lysosomes is a degradative pathway in dysfunctional mitochondria turnover which has been termed mitophagy [118]. Mitophagy is a key mode of action in keeping the cell healthy. It can prevent the accumulation of dysfunctional mitochondria, resulting in reduction of excess ROS. Besides, Mitophagy is required to adjust mitochondrial numbers to adapt to cell metabolic needs, for steady-state mitochondrial turnover and remove of mitochondria during cellular differentiation of red blood cells [118]. It was reported that elimination of damaged mitochondria by mitophagy through addition of rapamycin could reduce the ROS levels and increase the survival of T-2 toxin-treated yeast cells. This indicated that mitophagy could be a cellular protective approach against trichothecene-induced oxidative stress [18]. Another study also indicated that autophagy could be a favourable way in protecting the cells against the toxicity of DON. The deficiency in autophagy by knock-out (KO) of autophagyrelated gene 5 (ATG5) in porcine intestinal epithelial cells increased DON-induced apoptosis in Atg5-KO cells partly due to ROS generation. In addition, autophagy deficiency downregulated the endoplasmic reticulum folding proteins binding immunoglobulin protein and protein disulfide isomerase when Atg5-KO cells were treated with DON. This would ultimately create a harmful oxidant environment [119]. A schematic illustration of protective effects of various antioxidants against trichotheceneinduced oxidative stress and mitochondrial dysfunction is presented in Figure 4 and Table 2.

\section{CONCLUSION}

Mitochondria play critical roles in cellular energy metabolism, lipid metabolism, calcium uptake and 
release, redox homeostasis and apoptosis. Mitochondrial dysfunction exacerbate the damage caused by trichothecenes both through increasing ROS or decreasing the availability of ATP. The $\Delta \psi \mathrm{m}$ reflect the mitochondria functional status. $\Delta \psi \mathrm{m}$ collapse induced by trichothecenes is an early event in mitochondrial dysfunction, which will promote the ROS generation. Mitochondria act as a dynamic receiver and integrator of numerous lethal signals. These signals converge on mitochondria to cause the permeabilization of the mitochondrial outer and inner membrane, leading to the cytosolic release of proapoptotic proteins to activate apoptosis.

Trichothecenes can inhibit the enzyme activities of mitochondrial ETC complexes and decrease the mitochondrial oxygen consumption rate. These mycotoxins also inhibit the mitochondrial translation to decrease mitochondrial protein synthesis, which is independent of their effects on cytosolic translation. At the transcription level, trichothecenes can repress the expression of genes involved in mitochondrial translation like mitochondrial translation initiation/elongation factors and genes encoding the mitochondrial ribosomal proteins. The proteomics analysis also show that trichothecenes can inhibit the protein expression of the subunits of mitochondrial ETC, which may be result from the mitochondrial translation inhibition. The inhibition of mitochondrial protein synthesis may result in disruption of electron transfer in ETC, leading to ROS increase and ATP decrease. When the mitochondria is seriously damaged, mitophagy is initiated to selectively remove the mitochondria, keeping a proper redox environment for the cells.

Several questions that have not been interpreted fully arise now. Is RSR the origin of other toxic effects including

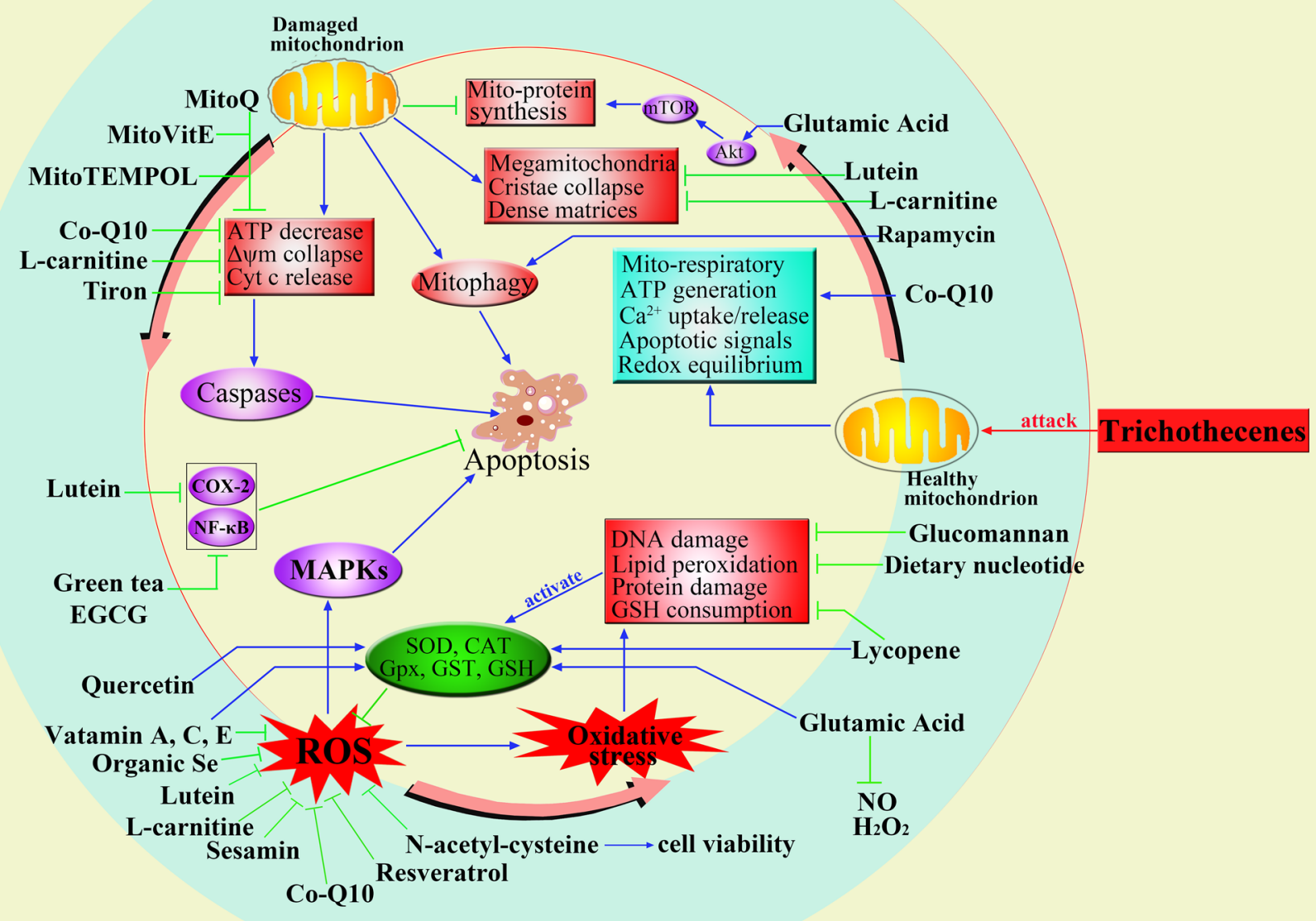

Figure 4: A schematic illustration of protective effects of various antioxidants against trichothecene-induced oxidative stress and mitochondrial dysfunction. Mito-respiratory and Mito-protein indicate mitochondrial respiratory and mitochondrial protein. 
Table 2: Summary of the antioxidant agents against trichothecenes

\begin{tabular}{l} 
Compounds \\
\hline In vivo studies \\
Vitamins C and E and selenium \\
(Se) \\
Lycopene \\
Ditary nucleotides (2 g/Kg) \\
binder (yeast cell wall extract)
\end{tabular}

Male broiler chicks

Male broiler chickens

Broiler chicken

Vitamin E (100 mg/Kg)

Organic Se (Se -yeast) $(1 \mathrm{mg} /$

$\mathrm{Kg})$

Glutamic Acid (concentration is $2 \%$ )

Glutamic Acid (2\%)

Combination of vitamin A, C, E, quercetin and organic Se

Male rats

Male pigs

Chickens of Ross

Piglets

Growing swine

Piglets

\section{Cells or animals}

Results/conclusion

Reference
DON or T-2 toxin increased lipid peroxidation, decreased GSH content and activities of CAT, SOD, cytochrome P450 and GST. Pre-treatment of antioxidants combat these effects and decreased the mortality of animals.

T-2 toxin increased hepatic MDA levels and enzymatic activities of GST and GSH-Px, and consumed the endogenous antioxidant GSH. However, lycopene diminished these effects.

T-2 toxin and DON induced DNA fragmentation in spleen leukocytes and decreased TAS, yet did not affect plasma and liver MDA. Nucleotides reduced the amount of damage only when added to T-2 toxin.

$\mathrm{T}-2$ toxin had a negative effect in ascorbic acid and glutathione redox system in blood plasma, red blood cells, liver and spleen tissue. The antioxidant and toxin binder had beneficial effect on the antioxidant status, primarily the activity of the GSH-Px.

T-2 toxin and DON did not significantly alter TAS, GSH-Px activities, plasma and urinary MDA levels, however significantly increased the amount of DNA damage in pig lymphocytes, Vitamin E partially reduced DNA damage.

DON significantly reduced blood phagocytic activity, increased the activity of GSH-Px in the duodenal mucosa.

Glutamic acid remarkably reduced DONinduced oxidative stress including serum concentrations of CAT, TAS, $\mathrm{H} 2 \mathrm{O} 2$, nitric oxide, MDA, and concentrations of $\mathrm{H} 2 \mathrm{O} 2$ and MDA in kidney, liver and small intestine

Glutamic acid significantly augmented serum T-SOD and GSH-Px activities, and ameliorated the abnormalities of intestinal structure caused by mycotoxins.

Combination of antioxidants reduced plasma and liver MDA content and SOD activity in liver of piglets fed DON contaminated diets. 


\begin{tabular}{|c|c|c|c|}
\hline Compounds & Cells or animals & Results/conclusion & Reference \\
\hline L-carnitine (50 and $500 \mathrm{mg} / \mathrm{Kg}$ ) & Male Wistar rats & $\begin{array}{l}\text { Pretreatment with l-carnitine combated } \\
\text { glutathione depletion, ROS generation and } \\
\Delta \Psi \text { m collapse and apoptosis after T-2 toxin } \\
\text { exposure. }\end{array}$ & [109] \\
\hline \multicolumn{4}{|l|}{ In vitro studies } \\
\hline Vitamin $\mathrm{C}, \mathrm{E}$ and Se & $\begin{array}{l}\text { Human gingival } \\
\text { fibroblast, colorectal } \\
\text { adenocarcinoma and } \\
\text { HepG2 }\end{array}$ & $\begin{array}{l}\text { Co-incubation of cell lines with different } \\
\text { concentrations of T- } 2 \text { toxin and antioxidants } \\
\text { decreased significantly, but did not totally } \\
\text { inhibit, the cytotoxicity of T- } 2 \text { toxin. }\end{array}$ & [126] \\
\hline Lutein $(10 \mu \mathrm{M})$ & HT-29 cells & $\begin{array}{l}\text { Pretreatment of lutein inhibited DON- } \\
\text { induced ROS, nitrite generation, } \\
\text { maintained GSH level, lowered DON- } \\
\text { induced increase of CAT, SOD, Gpx and } \\
\text { GST activities, inhibited the expression of } \\
\text { inflammatory genes, COX-2 and NF-kB } \\
\text { and induction of apoptosis }\end{array}$ & {$[20]$} \\
\hline $\mathrm{N}$-acetyl-cysteine & $\begin{array}{l}\text { Primary cultures of } \\
\text { chicken growth plate } \\
\text { chondrocytes }\end{array}$ & $\begin{array}{l}\text { T-2 toxin significantly increased ROS } \\
\text { and MDA levels, decreased cell viability, } \\
\text { alkaline phosphatase activity and GSH } \\
\text { levels. N-acetyl-cysteine partially reversed } \\
\text { the effects. }\end{array}$ & {$[127]$} \\
\hline Quercetin & Rabbit & $\begin{array}{l}\text { Chronic exposure to quercetin resulted } \\
\text { in increased ovarian cell proliferation } \\
\text { and reduced cell apoptosis after T- } 2 \text { toxin } \\
\text { exposure. }\end{array}$ & {$[128]$} \\
\hline Vitamin $\mathrm{C}(56.8 \mu \mathrm{M})$ & Rat cardiomyocytes & $\begin{array}{l}\text { Vitamin } \mathrm{C} \text { significantly inhibited } \mathrm{T}-2 \text { toxin } \\
\text { and DON-induced decrease in oxygen } \\
\text { consumption rates }\end{array}$ & {$[30]$} \\
\hline $\begin{array}{l}\text { Epigallocatechin-3-gallate } \\
\text { (EGCG) }(20 \mu \mathrm{M})\end{array}$ & HT-29 cells & $\begin{array}{l}\text { EGCG reduced DON-induced ROS, nitrite } \\
\text { production and protein carbonyl content, } \\
\text { maintained GSH level, lowered DON- } \\
\text { induced increase in CAT, SOD, Gpx and } \\
\text { GST activities, restored the membrane } \\
\text { potential, inhibited the expression of } \\
\text { inflammatory genes, COX-2 and NF-kB } \\
\text { and induction of apoptosis. }\end{array}$ & [101] \\
\hline Quercetin & $\begin{array}{l}\text { Porcine ovarian } \\
\text { granulosa cells }\end{array}$ & $\begin{array}{l}\text { Quercetin was effective in maintaining and } \\
\text { increasing of TAS, activities of SOD and } \\
\text { GSH-Px, but had no effect in elimination of } \\
\text { ROS generation induced by T- } 2 \text { toxin. }\end{array}$ & {$[100]$} \\
\hline Resveratrol (RES) & $\begin{array}{c}\text { Non-transformed } \\
\text { intestinal cell IPEC-J2 }\end{array}$ & $\begin{array}{l}\text { RES could protect against DON-induced } \\
\text { decrease in transepithelial electrical } \\
\text { resistance and increase in paracellular } \\
\text { permeability possibly through anti- } \\
\text { oxidative mechanism. }\end{array}$ & [129] \\
\hline $\begin{array}{l}\text { Combination of vitamin } \mathrm{E} \text { and } \\
\text { sesamin }\end{array}$ & Leydig cell line MA-10 & $\begin{array}{l}\text { A combination of vitamin } \mathrm{E} \text { and sesamin } \\
\text { significantly reduced ROS production and } \\
\text { increased cell survival after DON exposure. }\end{array}$ & {$[130]$} \\
\hline
\end{tabular}


mitochondrial dysfunction induced by trichothecenes? The current evidences show that trichothecenes can bind to the ribosomes and interfere with initiation, elongation and/or termination. Trichothecenes activate two kinases, double-stranded RNA-activated protein kinase (PKR) and hematopoietic cell kinase (Hck), which are two critical upstream sensor and transducer of RSR [131, 132]. The RSR-promoted activation of MARKs by trichothecenes mediate transcriptional and post-transcriptional gene upregulation through activating various transcription factors (TFs) like STATs, EGR1, c- JUN, c-Fos, ATF3, AP-1, C/EBP, CREB, p21, p53 and NF- $\mathrm{BB}$ that play central roles in gene expression, immune regulation, cell cycle, apoptosis and mitochondrial function $[3,132$, 133]. Probably, the activation of these TFs can regulate the expression of mitochondrial proteins in trichothecenetreated cells since most of the TFs have been shown to be linked to mitochondrial functions [17, 134, 135]. However, the evidence from Pace et al. and Bin-Umer et al. showed that trichothecenes could be absorbed by mitochondria [19] and directly inhibited the mitochondrial translation [55], suggesting that mitochondrial toxicity was not, at least not all, a downstream toxic effect of RSR.

Looking to the future, to develop possible antidotes against the adverse effects of trichothecenes is of great significance. Various natural compounds have been evaluated for their anti-oxidative effects. Many of these compounds also exhibit anti-inflammatory, anti-cancer properties and can combat the lipid peroxidation and DAN damage induced by mycotoxins. Specially, mitochondriatargeted antioxidants were shown to have favourable protective effects against trichothecene-induced oxidative stress and mitochondrial dysfunction. New strategies against trichothecenes are needed. Overexpression of two mitochondrial IM organic anion carriers, dicarboxylate and 2-oxoglutarate, can increase mitochondrial GSH. Importantly, elimination of damaged mitochondria through mitophagy shed new light on reducing mitochondrial oxidative stress caused by trichothecenes. Since trichothecenes are globally contaminants in cereals and can be accessed by people in the food chain, to find other effective ways to reduce the toxicity of trichothecenes are important aspects to be considered for future studies.

\section{Abbreviations}

4EBP1, eukaryotic initiation factor 4E-binding protein-1; $\triangle \Psi \mathrm{m}$, mitochondrial membrane potential; AIF, apoptosis-inducing factor; AGO, argonaute; AKT, protein kinase B; ANT, adenine nucleotide translocate; ATG5, autophagy-related gene 5; ATP, adenosine triphosphate; CAT, catalase; Co-Q10, Co-enzyme Q10; COX-2, cyclooxygenase-2; cyt-c, cytochrome c; CsA, cyclosporine A; DF-1, chicken embryo fibroblast cells; DON, deoxynivalenol; EGCG, green tea polyphenol epigallocatechin 3-gallate; ER, endoplasmic reticulum;
ERK, extracellular signal-regulated kinase; GSH, glutathione; GSH-Px, glutathione peroxidase; GST, glutathione S-transferases; Hck, hematopoietic cell kinase; Hela, human cervical cancer cells; HT-29, human colon carcinoma cells; MAPKs, mitogenactivated protein kinases; MDA, malondialdehyde; MMP, mitochondrial membrane permeabilization; MPTP, mitochondrial permeability transition pore; mTFA, mitochondrial transcription factor A; mTOR, mammalian target of rapamycin; mt-DNA, mitochondrial DNA; miRNA, microRNA; Mybbp-1 $\alpha$, My-binding protein $1 \alpha$; NO, nitric oxide; NRF, nuclear respiratory factor; P-bodies, processing bodies; PGC-1 $\alpha$, peroxisome proliferator-activated receptor- $\gamma$ co-activator $1 \alpha$; PI3K, phosphoinositide 3-kinase; PKR, double-stranded RNAactivated protein kinase; ROS, reactive oxygen species; Rpl3, ribosomal protein L3; RSR, ribotoxic stress response; RISC, RNA induced silencing complexes; S6K, ribosomal S6 kinase; SG, satratoxin G; SOD, superoxide dismutase; TAC, total antioxidant capacity; TFs, transcription factors; TPP, triphenylphosphonium; OXPHOS, oxidative phosphorylation; JNK, c-Jun N-terminal kinase;

\section{CONFLICTS OF INTEREST}

The authors declare that they have no conflicts of interest.

\section{FUNDING}

This work was supported by the National Natural Science Foundation of China (grant no. 31572575 and 31602114), the Fundamental Research Funds for the Central Universities (2662016PY115), and the project of Long-term development plan UHK.

\section{REFERENCES}

1. Yuan Z, Wu Q, Huang L, Liu Z, Yao M, Cao X, Wang Y, Dai M, Chen D, Pan Y, Tao Y, Peng D, Wang X, et al. Comparative metabolism of T-2 toxin by the fractions of hepatocytes from rats, pigs, chickens and carps. Drug Metab Rev. 2010; 42:219-220.

2. Wu Q, Dohnal V, Kuca K, Yuan Z. Trichothecenes: structure-toxic activity relationships. Curr Drug Metab. 2013; 14:641-660.

3. Arunachalam C, Doohan FM. Trichothecene toxicity in eukaryotes: cellular and molecular mechanisms in plants and animals. Toxicol Lett. 2013; 217:149-158.

4. Abbas HK, Yoshizawa T, Shier WT. Cytotoxicity and phytotoxicity of trichothecene mycotoxins produced by Fusarium spp. Toxicon. 2013; 74:68-75.

5. Wu Q, Wang X, Nepovimova E, Miron A, Liu Q, Wang Y, Su D, Yang H, Li L, Kuca K. Trichothecenes: 
immunomodulatory effects, mechanisms, and anti-cancer potential. Arch Toxicol. 2017; 91:3737-3785.

6. Payros D, Alassane-Kpembi I, Pierron A, Loiseau N, Pinton P, Oswald IP. Toxicology of deoxynivalenol and its acetylated and modified forms. Arch Toxicol. 2016; 90:2931-2957.

7. Kugler KG, Jandric Z, Beyer R, Klopf E, Glaser W, Lemmens M, Shams M, Mayer K, Adam G, Schuller C. Ribosome quality control is a central protection mechanism for yeast exposed to deoxynivalenol and trichothecin. BMC Genomics. 2016; 17:417.

8. Li M, Pestka JJ. Comparative induction of $28 \mathrm{~S}$ ribosomal RNA cleavage by ricin and the trichothecenes deoxynivalenol and T-2 toxin in the macrophage. Toxicol Sci. 2008; 105:67-78.

9. He K, Zhou HR, Pestka JJ. Mechanisms for ribotoxininduced ribosomal RNA cleavage. Toxicol Appl Pharmacol. 2012; 265:10-18.

10. Bae HK, Shinozuka J, Islam Z, Pestka JJ. Satratoxin G interaction with $40 \mathrm{~S}$ and $60 \mathrm{~S}$ ribosomal subunits precedes apoptosis in the macrophage. Toxicol Appl Pharmacol. 2009; 237:137-145.

11. Di R, Blechl A, Dill-Macky R, Tortora A, Tumer NE. Expression of a truncated form of yeast ribosomal protein L3 in transgenic wheat improves resistance to Fusarium head blight. Plant Sci. 2010; 178:374-380.

12. Kumari I, Ahmed M, Akhter Y. Deciphering the protein translation inhibition and coping mechanism of trichothecene toxin in resistant fungi. Int J Biochem Cell Biol. 2016; 78:370-376.

13. Di R, Tumer NE. Expression of a truncated form of ribosomal protein L3 confers resistance to pokeweed antiviral protein and the Fusarium mycotoxin deoxynivalenol. Mol Plant Microbe Interact. 2005; 18:762-770.

14. Afshar AS, Mousavi A, Majd A, Renu, Adam G. Double mutation in tomato ribosomal protein L3 cDNA confers tolerance to deoxynivalenol (DON) in transgenic tobacco. Pak J Biol Sci. 2007; 10:2327-2333.

15. Pan X, Whitten DA, Wu M, Chan C, Wilkerson CG, Pestka JJ. Early phosphoproteomic changes in the mouse spleen during deoxynivalenol-induced ribotoxic stress. Toxicol Sci. 2013; 135:129-143.

16. Wang Z, Wu Q, Kuca K, Dohnal V, Tian Z. Deoxynivalenol: signaling pathways and human exposure risk assessment-an update. Arch Toxicol. 2014; 88:1915-1928.

17. Liu XL, Guo P, Liu AM, Wu QH, Xue XJ, Dai MH, Hao HH, Qu W, Xie SY, Wang X, Yuan ZH. Nitric oxide (NO)mediated mitochondrial damage plays a critical role in $\mathrm{T}-2$ toxin-induced apoptosis and growth hormone deficiency in rat anterior pituitary GH3 cells. Food Chem Toxicol. 2017; 102:11-23

18. Bin-Umer MA, McLaughlin JE, Butterly MS, McCormick $\mathrm{S}$, Tumer NE. Elimination of damaged mitochondria through mitophagy reduces mitochondrial oxidative stress and increases tolerance to trichothecenes. Proc Natl Acad Sci U S A. 2014; 111:11798-11803.

19. Pace JG, Watts MR, Canterbury WJ. T-2 mycotoxin inhibits mitochondrial protein synthesis. Toxicon. 1988; 26:77-85.

20. Krishnaswamy R, Devaraj SN, Padma VV. Lutein protects HT-29 cells against Deoxynivalenol-induced oxidative stress and apoptosis: prevention of NF-kappaB nuclear localization and down regulation of NF-kappaB and CycloOxygenase-2 expression. Free Radic Biol Med. 2010; 49:50-60.

21. Trusal LR, O'Brien JC. Ultrastructural effects of T-2 mycotoxin on rat hepatocytes in vitro. Toxicon. 1986; 24:481-488.

22. Huang DY, Cui LQ, Guo P, Xue XJ, Wu QH, Hussain HI, Wang X, Yuan ZH. Nitric oxide mediates apoptosis and mitochondrial dysfunction and plays a role in growth hormone deficiency by nivalenol in GH3 cells. Sci Rep-UK. 2017; 7:17079.

23. Fang HQ, Wu YL, Guo JB, Rong J, Ma L, Zhao ZM, Zuo DY, Peng SQ. T-2 toxin induces apoptosis in differentiated murine embryonic stem cells through reactive oxygen species-mediated mitochondrial pathway. Apoptosis. 2012; 17:895-907.

24. Li D, Ye Y, Lin S, Deng L, Fan X, Zhang Y, Deng X, Li Y, Yan H, Ma Y. Evaluation of deoxynivalenol-induced toxic effects on DF-1 cells in vitro: cell-cycle arrest, oxidative stress, and apoptosis. Environ Toxicol Pharmacol. 2014; 37:141-149.

25. Josse L, Li X, Coker RD, Gourlay CW, Evans IH. Transcriptomic and phenotypic analysis of the effects of T-2 toxin on Saccharomyces cerevisiae: evidence of mitochondrial involvement. FEMS Yeast Res. 2011; 11:133-150.

26. Arya R, White K. Cell death in development: signaling pathways and core mechanisms. Semin Cell Dev Biol. 2015; 39:12-19.

27. Xiong SB, Mu TY, Wang GW, Jiang XJ. Mitochondriamediated apoptosis in mammals. Protein Cell. 2014; 5:737-749.

28. Martinou JC, Youle RJ. Mitochondria in apoptosis: Bcl-2 family members and mitochondrial dynamics. Dev Cell. 2011; 21:92-101.

29. Galluzzi L, Kepp O, Trojel-Hansen C, Kroemer G. Mitochondrial control of cellular life, stress, and death. Circ Res. 2012; 111:1198-1207.

30. Ngampongsa S, Hanafusa M, Ando K, Ito K, Kuwahara M, Yamamoto Y, Yamashita M, Tsuru Y, Tsubone H. Toxic effects of T-2 toxin and deoxynivalenol on the mitochondrial electron transport system of cardiomyocytes in rats. J Toxicol Sci. 2013; 38:495-502.

31. Rasheed MZ, Tabassum H, Parvez S. Mitochondrial permeability transition pore: a promising target for the treatment of Parkinson's disease. Protoplasma. 2017; $254: 33-42$. 
32. Liu J, Wang L, Guo X, Pang Q, Wu S, Wu C, Xu P, Bai Y. The role of mitochondria in T-2 toxin-iHuman chondrocytes apoptosis. Plos One. 2014; 9.

33. Wang XC, Xu W, Fan MX, Meng TT, Chen XF, Jiang YJ, Zhu DF, Hu WJ, Gong JJ, Feng SB, Wu JJ, Li Y. Deoxynivalenol induces apoptosis in PC12 cells via the mitochondrial pathway. Environ Toxicol Phar. 2016; 43:193-202.

34. Aupanun S, Phuektes P, Poapolathep S, Sutjarit S, Giorgi M, Poapolathep A. Apoptosis and gene expression in Jurkat human T cells and lymphoid tissues of fusarenon-X-treated mice. Toxicon. 2016; 123:15-24.

35. Bouaziz C, Martel C, Sharaf el dein O, Abid-Essefi S, Brenner C, Lemaire C, Bacha H. Fusarial toxin-induced toxicity in cultured cells and in isolated mitochondria involves PTPC-dependent activation of the mitochondrial pathway of apoptosis. Toxicol Sci. 2009; 110:363-375.

36. Wu J, Jing L, Yuan H, Peng SQ. T-2 toxin induces apoptosis in ovarian granulosa cells of rats through reactive oxygen species-mediated mitochondrial pathway. Toxicol Lett. 2011; 202:168-177.

37. Bensassi F, Gallerne C, Sharaf El Dein O, Lemaire C, Hajlaoui MR, Bacha H. Involvement of mitochondriamediated apoptosis in deoxynivalenol cytotoxicity. Food Chem Toxicol. 2012; 50:1680-1689.

38. Ren Z, Wang Y, Deng H, Deng Y, Deng J, Zuo Z, Wang Y, Peng X, Cui H, Shen L. Deoxynivalenol induces apoptosis in chicken splenic lymphocytes via the reactive oxygen species-mediated mitochondrial pathway. Environ Toxicol Pharmacol. 2015; 39:339-346.

39. Zorov DB, Juhaszova M, Sollott SJ. Mitochondrial reactive oxygen species (ROS) and ROS-induced ROS release. Physiol Rev. 2014; 94:909-950.

40. Sorrentino L, Calogero AM, Pandini V, Vanoni MA, Sevrioukova IF, Aliverti A. Key role of the adenylate moiety and integrity of the adenylate-binding site for the $\mathrm{NAD}(+) / \mathrm{H}$ binding to mitochondrial apoptosis-inducing factor. Biochemistry. 2015; 54:6996-7009.

41. Chaudhari M, Jayaraj R, Bhaskar AS, Lakshmana Rao PV. Oxidative stress induction by T-2 toxin causes DNA damage and triggers apoptosis via caspase pathway in human cervical cancer cells. Toxicology. 2009; 262:153-161.

42. Islam Z, Hegg CC, Bae HK, Pestka JJ. Satratoxin G-induced apoptosis in PC-12 neuronal cells is mediated by PKR and caspase independent. Toxicol Sci. 2008; 105:142-152.

43. Sazanov LA. A giant molecular proton pump: structure and mechanism of respiratory complex I. Nat Rev Mol Cell Bio. 2015; 16:375-388.

44. Feissner RF, Skalska J, Gaum WE, Sheu SS. Crosstalk signaling between mitochondrial $\mathrm{Ca} 2+$ and ROS. Frontiers in Bioscience-Landmark. 2009; 14:1197-1218.

45. Valko M, Leibfritz D, Moncol J, Cronin MT, Mazur M, Telser J. Free radicals and antioxidants in normal physiological functions and human disease. Int J Biochem Cell Biol. 2007; 39:44-84.

46. Koshinsky H, Honour S, Khachatourians G. T-2 toxin inhibits mitochondrial function in yeast. Biochem Bioph Res Co. 1988; 151:809-814.

47. McLaughlin JE, Bin-Umer MA, Tortora A, Mendez N, McCormick S, Tumer NE. A genome-wide screen in Saccharomyces cerevisiae reveals a critical role for the mitochondria in the toxicity of a trichothecene mycotoxin. Proc Natl Acad Sci U S A. 2009; 106:21883-21888.

48. Villena JA. New insights into PGC-1 coactivators: redefining their role in the regulation of mitochondrial function and beyond. FEBS J. 2015; 282:647-672.

49. Scarpulla RC. Transcriptional paradigms in mammalian mitochondrial biogenesis and function. Physiol Rev. 2008; 88:611-638.

50. Wu KM, Zhao ZX, Xiao YL, Peng JJ, Chen JH, He YL. Roles of mitochondrial transcription factor $\mathrm{A}$ and microRNA-590-3p in the development of colon cancer. Mol Med Rep. 2016; 14:5475-5480.

51. Osman AM, Pennings JL, Blokland M, Peijnenburg A, van Loveren H. Protein expression profiling of mouse thymoma cells upon exposure to the trichothecene deoxynivalenol (DON): implications for its mechanism of action. J Immunotoxicol. 2010; 7:147-156.

52. Fang HQ, Cong LZ, Zhi Y, Xu HB, Jia XD, Peng SQ. T-2 toxin inhibits murine ES cells cardiac differentiation and mitochondrial biogenesis by ROS and p-38 MAPKmediated pathway. Toxicol Lett. 2016; 258:259-266.

53. Wu MM, Xiao H, Ren WK, Yin J, Tan B, Liu G, Li L, Nyachoti CM, Xiong X, Wu GY. Therapeutic effects of glutamic acid in piglets challenged with deoxynivalenol. Plos One. 2014; 9:12.

54. Cunningham JT, Rodgers JT, Arlow DH, Vazquez F, Mootha VK, Puigserver P. mTOR controls mitochondrial oxidative function through a YY1-PGC-1 alpha transcriptional complex. Nature. 2007; 450:736-740.

55. Bin-Umer MA, McLaughlin JE, Basu D, McCormick S, Tumer NE. Trichothecene mycotoxins inhibit mitochondrial translation--implication for the mechanism of toxicity. Toxins (Basel). 2011; 3:1484-1501.

56. Suzuki T, Iwahashi Y. Comprehensive gene expression analysis of type B trichothecenes. J Agric Food Chem. 2012; 60:9519-9527.

57. Katika MR, Hendriksen PJ, Shao J, van Loveren H, Peijnenburg A. Transcriptome analysis of the human $\mathrm{T}$ lymphocyte cell line Jurkat and human peripheral blood mononuclear cells exposed to deoxynivalenol (DON): new mechanistic insights. Toxicol Appl Pharmacol. 2012; 264:51-64.

58. Gopisetty G, Thangarajan R. Mammalian mitochondrial ribosomal small subunit (MRPS) genes: a putative role in human disease. Gene. 2016; 589:27-35. 
59. Mu P, Xu M, Zhang L, Wu K, Wu J, Jiang J, Chen Q, Wang L, Tang X, Deng Y. Proteomic changes in chicken primary hepatocytes exposed to T-2 toxin are associated with oxidative stress and mitochondrial enhancement. Proteomics. 2013; 13:3175-3188.

60. Wang J, Jiang J, Zhang H, Wang J, Cai H, Li C, Li K, Liu J, Guo X, Zou G, Wang D, Deng Y, Dai J. Integrated transcriptional and proteomic analysis with in vitro biochemical assay reveal the important role of CYP3A46 in T-2 toxin hydroxylation in porcine primary hepatocytes. Mol Cell Proteomics. 2011; 10.

61. Wan D, Wang X, Wu Q, Lin P, Pan Y, Sattar A, Huang L, Ahmad I, Zhang Y, Yuan Z. Integrated transcriptional and proteomic analysis of growth hormone suppression mediated by trichothecene T-2 toxin in rat GH3 cells. Toxicol Sci. 2015; 147:326-338.

62. Sehata S, Kiyosawa N, Makino T, Atsumi F, Ito K, Yamoto T, Teranishi M, Baba Y, Uetsuka K, Nakayama H, Doi $\mathrm{K}$. Morphological and microarray analysis of T-2 toxininduced rat fetal brain lesion. Food Chem Toxicol. 2004; 42:1727-1736.

63. Jacquemin G, Margiotta D, Kasahara A, Bassoy EY, Walch M, Thiery J, Lieberman J, Martinvalet D. Granzyme B-induced mitochondrial ROS are required for apoptosis. Cell Death Differ. 2015; 22:862-874.

64. Wang WX, Sullivan PG, Springer JE. Mitochondria and microRNA crosstalk in traumatic brain injury. Prog NeuroPsychoph. 2017; 73:104-108.

65. Sripada L, Tomar D, Singh R. Mitochondria: one of the destinations of miRNAs. Mitochondrion. 2012; 12:593-9.

66. Bienertova-Vasku J, Sana J, Slaby O. The role of microRNAs in mitochondria in cancer. Cancer Lett. 2013; 336:1-7.

67. Ferrari D, Bianchi N, Eltzschig HK, Gambari R. MicroRNAs modulate the purinergic signaling network. Trends Mol Med. 2016; 22:905-918.

68. Wang WX, Visavadiya NP, Pandya JD, Nelson PT, Sullivan PG, Springer JE. Mitochondria-associated microRNAs in rat hippocampus following traumatic brain injury. Exp Neurol. 2015; 265:84-93.

69. Bandiera S, Ruberg S, Girard M, Cagnard N, Hanein S, Chretien D, Munnich A, Lyonnet S, Henrion-Caude A. Nuclear outsourcing of RNA interference components to human mitochondria. PloS One. 2011; 6:e20746.

70. Bian Z, Li LM, Tang R, Hou DX, Chen X, Zhang CY, Zen $\mathrm{K}$. Identification of mouse liver mitochondria-associated miRNAs and their potential biological functions. Cell Res. 2010; 20:1076-1078.

71. Wu H, Wang J, Ma H, Xiao Z, Dong X. MicroRNA-21 inhibits mitochondria-mediated apoptosis in keloid. Oncotarget. 2017; 8:92914-92925. https://doi.org/10.18632/ oncotarget.21656a.

72. Li W, Chen H, Li S, Lin G, Feng D. Exploring microRNAs on NIX-dependent mitophagy. Methods Mol Biol. 2017.
73. Wang K, Long B, Jiao JQ, Wang JX, Liu JP, Li Q, Li PF. miR-484 regulates mitochondrial network through targeting Fis1. Nat Commun. 2012; 3:781.

74. Sun W, Zhao L, Song X, Zhang J, Xing Y, Liu N, Yan Y, Li Z, Lu Y, Wu J, Li L, Xiao Y, Tian X, et al. MicroRNA-210 modulates the cellular energy metabolism shift during $\mathrm{H} 2 \mathrm{O} 2$-induced oxidative stress by repressing ISCU in H9c2 cardiomyocytes. Cell Physiol Biochem. 2017; 43:383-394.

75. Huang L, Mollet S, Souquere S, Le Roy F, Ernoult-Lange M, Pierron G, Dautry F, Weil D. Mitochondria associate with P-bodies and modulate microRNA-mediated RNA interference. J Biol Chem. 2011; 286:24219-24230.

76. Lee S, Lim S, Ham O, Lee SY, Lee CY, Park JH, Lee J, Seo HH, Yun I, Han SM, Cha MJ, Choi E, Hwang KC. ROS-mediated bidirectional regulation of miRNA results in distinct pathologic heart conditions. Biochem Bioph Res Co. 2015 ; 465:349-355.

77. He K, Pestka J. Deoxynivalenol-induced modulation of microRNA expression in RAW 264.7 macrophages-A potential novel mechanism for translational inhibition. Toxicol Sci. 2010; 114:310.

78. Brzuzan P, Wozny M, Wolinska-Niziol L, Piasecka A, Florczyk M, Jakimiuk E, Gora M, Luczynski MK, Gajecki M. MicroRNA expression profiles in liver and colon of sexually immature gilts after exposure to Fusarium mycotoxins. Pol J Vet Sci. 2015; 18:29-38.

79. Schramedei K, Morbt N, Pfeifer G, Lauter J, Rosolowski $\mathrm{M}$, Tomm JM, von Bergen M, Horn F, Brocke-Heidrich K. MicroRNA-21 targets tumor suppressor genes ANP32A and SMARCA4. Oncogene. 2011; 30:2975-2985.

80. Li HP, Zhang XR, Wang F, Zhou L, Yin ZW, Fan JH, Nie X, Wang PH, Fu XD, Chen C, Wang DW. MicroRNA-21 lowers blood pressure in spontaneous hypertensive rats by upregulating mitochondrial translation. Circulation. 2016; 134:734-751.

81. Ofir M, Hacohen D, Ginsberg D. miR-15 and miR-16 are direct transcriptional targets of E2F1 that limit E2F-induced proliferation by targeting cyclin E. Mol Cancer Res. 2011; 9:440-447.

82. Patel N, Garikapati KR, Ramaiah MJ, Polavarapu KK, Bhadra U, Bhadra MP. miR-15a/miR-16 induces mitochondrial dependent apoptosis in breast cancer cells by suppressing oncogene BMI1. Life Sci. 2016; 164:60-70.

83. Guo J, Yang Z, Yang X, Li T, Liu M, Tang H. miR-346 functions as a pro-survival factor under ER stress by activating mitophagy. Cancer Lett. 2018; 413:69-81.

84. Yang F, Li T, Dong Z, Mi R. MicroRNA-410 is involved in mitophagy after cardiac ischemia/reperfusion injury by targeting high-mobility group box 1 protein. J Cell Biochem. 2018; 119:2427-2439.

85. Du JK, Cong BH, Yu Q, Wang H, Wang L, Wang CN, Tang XL, Lu JQ, Zhu XY, Ni X. Upregulation of microRNA-22 contributes to myocardial ischemia-reperfusion injury by 
interfering with the mitochondrial function. Free Radical Bio Med. 2016; 96:406-417.

86. Dahlmans D, Houzelle A, Andreux P, Jorgensen JA, Wang X, de Windt LJ, Schrauwen P, Auwerx J, Hoeks J. An unbiased silencing screen in muscle cells identifies miR320a, miR-150, miR-196b, and miR-34c as regulators of skeletal muscle mitochondrial metabolism. Mol Metab. 2017; 6:1429-1442.

87. Wang XX, Song C, Zhou X, Han XR, Li J, Wang ZW, Shang HB, Liu YL, Cao HQ. Mitochondria associated microRNA expression profiling of heart failure. Biomed Res Int. 2017.

88. Kren BT, Wong PY, Sarver A, Zhang XX, Zeng Y, Steer CJ. MicroRNAs identified in highly purified liver-derived mitochondria may play a role in apoptosis. RNA Biol. 2009; 6:65-72.

89. Barrey E, Saint-Auret G, Bonnamy B, Damas D, Boyer O, Gidrol X. Pre-microRNA and mature microRNA in human mitochondria. Plos One. 2011; 6:e20220.

90. Sripada L, Tomar D, Prajapati P, Singh R, Singh AK, Singh R. Systematic analysis of small RNAs associated with human mitochondria by deep sequencing: detailed analysis of mitochondrial associated miRNA. Plos One. 2012; 7:e44873.

91. Shinde S, Bhadra U. A complex genome-microRNA interplay in human mitochondria. Biomed Res Int. 2015; 2015:206382.

92. Mishra S, Tripathi A, Chaudhari BP, Dwivedi PD, Pandey HP, Das M. Deoxynivalenol induced mouse skin cell proliferation and inflammation via MAPK pathway. Toxicol Appl Pharmacol. 2014; 279:186-197.

93. Agrawal M, Bhaskar AS, Rao PV. Involvement of mitogenactivated protein hinase pathway in T-2 toxin-induced cell cycle alteration and apoptosis in human neuroblastoma cells. Mol Neurobiol. 2015; 51:1379-1394.

94. Wu Q, Wang X, Wan D, Li J, Yuan Z. Crosstalk of JNK1STAT3 is critical for RAW264.7 cell survival. Cellu Signal. 2014; 26:2951-2960

95. Albarenque SM, Doi K. T-2 toxin-induced apoptosis in rat keratinocyte primary cultures. Exp Mol Pathol. 2005; 78:144-149.

96. Kankkunen P, Valimaki E, Rintahaka J, Palomaki J, Nyman $\mathrm{T}$, Alenius $\mathrm{H}$, Wolff $\mathrm{H}$, Matikainen S. Trichothecene mycotoxins activate NLRP3 inflammasome through a P2X7 receptor and Src tyrosine kinase dependent pathway. Hum Immunol. 2014; 75:134-140.

97. Sehata S, Kiyosawa N, Atsumi F, Ito K, Yamoto T, Teranishi M, Uetsuka K, Nakayama H, Doi K. Microarray analysis of T-2 toxin-induced liver, placenta and fetal liver lesions in pregnant rats. Exp Toxicol Pathol. 2005; 57:15-28.

98. Albarenque SM, Suzuki K, Shinozuka J, Nakayama H, Doi K. Kinetics of apoptosis-related genes mRNA expression in the dorsal skin of hypotrichotic WBN/ILA-ht rats after topical application of T-2 toxin. Exp Toxicol Pathol. 2001; 52:553-556.

99. Jang S, Yu LR, Abdelmegeed MA, Gao Y, Banerjee A, Song BJ. Critical role of c-jun N-terminal protein kinase in promoting mitochondrial dysfunction and acute liver injury. Redox Bio. 2015; 6:552-564.

100. Capcarova M, Petruska P, Zbynovska K, Kolesarova A, Sirotkin AV. Changes in antioxidant status of porcine ovarian granulosa cells after quercetin and T-2 toxin treatment. J Environ Sci Heal B. 2015; 50:201-206.

101. Kalaiselvi P, Rajashree K, Priya LB, Padma VV. Cytoprotective effect of epigallocatechin-3-gallate against deoxynivalenol-induced toxicity through anti-oxidative and anti-inflammatory mechanisms in HT-29 cells. Food Chem Toxicol. 2013; 56:110-118.

102. Wu QH, Liu L, Miron A, Klimova B, Wan D, Kuca K. The antioxidant, immunomodulatory, and anti-inflammatory activities of Spirulina: an overview. Arch Toxicol. 2016; 90:1817-1840.

103. Frankic T, Pajk T, Rezar V, Levart A, Salobir J. The role of dietary nucleotides in reduction of DNA damage induced by T-2 toxin and deoxynivalenol in chicken leukocytes. Food Chem Toxicol. 2006; 44:1838-1844.

104. Frankic T, Salobir J, Rezar V. The effect of vitamin E supplementation on reduction of lymphocyte DNA damage induced by T-2 toxin and deoxynivalenol in weaned pigs. Anim Feed Sci Tech. 2008; 141:274-286.

105. Dvorska JE, Pappas AC, Karadas F, Speake BK, Surai PF. Protective effect of modified glucomannans and organic selenium against antioxidant depletion in the chicken liver due to T-2 toxin-contaminated feed consumption. Comp Biochem Phys C. 2007; 145:582-587.

106. Rizzo AF, Atroshi F, Ahotupa M, Sankari S, Elovaara E. Protective effect of antioxidants against free radicalmediated lipid peroxidation induced by DON or T-2 toxin. Zentralblatt fur Veterinarmedizin Reihe A. 1994; 41:81-90.

107. Wang XM, Zuo ZC, Zhao CP, Zhang Z, Peng GN, Cao SZ, $\mathrm{Hu}$ YC, Yu SM, Zhong ZJ, Deng JL, Ren ZH. Protective role of selenium in the activities of antioxidant enzymes in piglet splenic lymphocytes exposed to deoxynivalenol. Environ Toxicol Phar. 2016; 47:53-61.

108. Ajith TA, Jayakumar TG. Mitochondria-targeted agents: future perspectives of mitochondrial pharmaceutics in cardiovascular diseases. World J Cardiol. 2014; 6:1091-1099.

109. Moosavi M, Rezaei M, Kalantari H, Behfar A, Varnaseri G. 1-carnitine protects rat hepatocytes from oxidative stress induced by T-2 toxin. Drug and Chem Toxicol. 2016; 39:445-450.

110. Quinzii CM, Garone C, Emmanuele V, Tadesse S, Krishna S, Dorado B, Hirano M. Tissue-specific oxidative stress and loss of mitochondria in CoQ-deficient Pdss2 mutant mice. FZASEB J. 2013; 27:612-621. 
111. Atroshi F, Rizzo A, Biese I, Veijalainen P, Antila E, Westermarck T. T-2 toxin-induced DNA damage in mouse livers: the effect of pretreatment with coenzyme Q10 and alpha-tocopherol. Mol Aspects Med. 1997; 18:S255-8.

112. Atroshi F, Rizzo A, Westermarck T, Ali-vehmas T. Effects of tamoxifen, melatonin, coenzyme Q10, and L-carnitine supplementation on bacterial growth in the presence of mycotoxins. Pharmacol Res. 1998; 38:289-295.

113. Apostolova N, Victor VM. Molecular strategies for targeting antioxidants to mitochondria: therapeutic implications. Antioxid Redox Sign. 2015; 22:686-729.

114. Lash LH. Mitochondrial glutathione in diabetic nephropathy. J Clin Med. 2015; 4:1428-1447.

115. Jin H, Kanthasamy A, Ghosh A, Anantharam V, Kalyanaraman B, Kanthasamy AG. Mitochondriatargeted antioxidants for treatment of Parkinson's disease: preclinical and clinical outcomes. Biochim Biophys Acta. 2014; 1842:1282-1294.

116. Han YH, Park WH. Tiron, a ROS scavenger, protects human lung cancer Calu- 6 cells against antimycin A-induced cell death. Oncol Rep. 2009; 21:253-261.

117. Oyewole AO, Birch-Machin MA. Mitochondria-targeted antioxidants. FASEB J. 2015; 29:4766-4771.

118. Bingol B, Sheng M. Mechanisms of mitophagy: PINK1, Parkin, USP30 and beyond. Free Radical Bio Med. 2016; 100:210-222.

119. Tang Y, Li J, Li F, Hu CA, Liao P, Tan K, Tan B, Xiong X, Liu G, Li T, Yin Y. Autophagy protects intestinal epithelial cells against deoxynivalenol toxicity by alleviating oxidative stress via IKK signaling pathway. Free Radic Biol Med. 2015; 89:944-951.

120. Leal M, Shimada A, Ruiz F, Gonzalez de Mejia E. Effect of lycopene on lipid peroxidation and glutathione-dependent enzymes induced by T-2 toxin in vivo. Toxicol Lett. 1999; 109:1-10.

121. Weber M, Balogh K, Erdelyi M, Mezes M. Effect of T-2 toxin in combination with vitamin E, selenium and mycotoxin binder on lipid peroxide status and on the glutathione redox system in broiler chicken. J Poult Sci. 2006; 43:222-227.

122. Frankic T, Salobir J, Rezar V. The effect of vitamin E supplementation on reduction of lymphocyte DNA damage induced by T-2 toxin and deoxynivalenol in weaned pigs. Anim Feed Sci Tech. 2008; 141:274-286.

123. Placha I, Borutova R, Gresakova L, Petrovic V, Faix S, Leng L. Effects of excessive selenium supplementation to diet contaminated with deoxynivalenol on blood phagocytic activity and antioxidative status of broilers. J Anim Physiol Anim Nutr (Berl).. 2009; 93:695-702.

124. Duan JL, Yin J, Wu MM, Liao P, Deng D, Liu G, Wen QQ, Wang YF, Qiu W, Liu Y, Wu XL, Ren WK, Tan B, et al. Dietary glutamate supplementation ameliorates mycotoxin-induced abnormalities in the intestinal structure and expression of amino acid transporters in young pigs. Plos One. 2014; 9:10.

125. Thanh BV, Lemay M, Bastien A, Lapointe J, Lessard M, Chorfi Y, Guay F. The potential effects of antioxidant feed additives in mitigating the adverse effects of corn naturally contaminated with Fusarium mycotoxins on antioxidant systems in the intestinal mucosa, plasma, and liver in weaned pigs. Mycotoxin Res. 2016; 32:99-116.

126. Shokri F, Heidari M, Gharagozloo S, Ghazi-Khansari M. In vitro inhibitory effects of antioxidants on cytotoxicity of T-2 toxin. Toxicology. 2000; 146:171-176.

127. He SJ, Hou JF, Dai YY, Zhou ZL, Deng YF. N-acetyl-cysteine protects chicken growth plate chondrocytes from T-2 toxininduced oxidative stress. J Appl Toxicol. 2012; 32:980-985.

128. Lesniak-Walentyn A, Kolesarova A, Medvedova M, Maruniakova N, Capcarova M, Kalafova A, Hrabia A, Sirotkin AV. Proliferation and apoptosis in the rabbit ovary after administration of T-2 toxin and quercetin. J Anim Feed Sci. 2013; 22:264-271.

129. Ling KH, Wan ML, El-Nezami H, Wang M. Protective capacity of resveratrol, a natural polyphenolic compound, against deoxynivalenol-induced intestinal barrier dysfunction and bacterial translocation. Chem Res Toxicol. 2016; 29:823-833.

130. Savard C, Nogues P, Boyer A, Chorfi Y. Prevention of deoxynivalenol- and zearalenone-associated oxidative stress does not restore MA-10 Leydig cell functions. Toxicology. 2016; 341:17-27.

131. Bae H, Gray JS, Li M, Vines L, Kim J, Pestka JJ. Hematopoietic cell kinase associates with the $40 \mathrm{~S}$ ribosomal subunit and mediates the ribotoxic stress response to deoxynivalenol in mononuclear phagocytes. Toxicol Sci. 2010; 115:444-452.

132. Zhou HR, He KY, Landgraf J, Pan X, Pestka JJ. Direct activation of ribosome-associated double-stranded RNAdependent protein kinase (PKR) by deoxynivalenol, anisomycin and ricin: a new model for ribotoxic stress response induction. Toxins. 2014; 6:3406-3425.

133. Nielsen C, Lippke H, Didier A, Dietrich R, Martlbauer E. Potential of deoxynivalenol to induce transcription factors in human hepatoma cells. Mol Nutr Food Res. 2009; 53:479-491.

134. Liu X, Huang D, Guo P, Wu Q, Dai M, Cheng G, Hao H, Xie S, Yuan Z, Wang X. PKA/CREB and NF-kappaB pathway regulates AKNA transcription: a novel insight into $\mathrm{T}-2$ toxin-induced inflammation and GH deficiency in GH3 cells. Toxicology. 2017; 392:81-95.

135. Dai C, Ciccotosto GD, Cappai R, Wang Y, Tang S, Hoyer D, Schneider EK, Velkov T, Xiao X. Rapamycin confers neuroprotection against colistin-induced oxidative stress, mitochondria dysfunction and apoptosis through the activation of autophagy and mTOR/Akt/CREB signaling pathways. ACS Chem Neurosci. 2018. 